NBER WORKING PAPER SERIES

\title{
CROSS-BORDER PRUDENTIAL POLICY SPILLOVERS: HOW MUCH? HOW IMPORTANT? EVIDENCE FROM THE INTERNATIONAL BANKING RESEARCH NETWORK
}

\author{
Claudia M. Buch \\ Linda Goldberg
}

Working Paper 22874

http://www.nber.org/papers/w22874

\author{
NATIONAL BUREAU OF ECONOMIC RESEARCH \\ 1050 Massachusetts Avenue \\ Cambridge, MA 02138 \\ December 2016
}

The authors thank participants of the International Banking Research Network, in particular Matthieu Bussiere, Jana Ohls, and Dennis Reinhardt, for many thoughtful exchanges and contributions. Special thanks go to the teams that prepared the prudential instruments database (Eugenio Cerutti, Ricardo Correa, Elisabetta Fiorentino, and Esther Segalla) in collaboration with the International Monetary Fund and to all country teams providing the input for the metaanalysis. Simone Auer, Stijn Claessens, Ricardo Correa, Ralph De Haas, John Driscoll, Martial Dupaigne, Peter Egger, Alexander Guembel, Galina Hale, Robert Hills, Christian Hellwig, Augustin Landier, Ouarda Merrouche, Camelia Minoiu, Gianmarco Ottaviano, Alexander Popov, Rhiannon Sowerbutts, and Phil Strahan provided valuable comments on an earlier draft of this paper. Excellent research assistance was provided by Jacob Conway and Guzel Valitova. The views expressed in this paper are solely those of the authors and should not be interpreted as reflecting the view of the Federal Reserve Bank of New York, the Federal Reserve System, the Deutsche Bundesbank, or the National Bureau of Economic Research. All errors are our own.

NBER working papers are circulated for discussion and comment purposes. They have not been peer-reviewed or been subject to the review by the NBER Board of Directors that accompanies official NBER publications.

(C) 2016 by Claudia M. Buch and Linda Goldberg. All rights reserved. Short sections of text, not to exceed two paragraphs, may be quoted without explicit permission provided that full credit, including $\odot$ notice, is given to the source. 
Cross-Border Prudential Policy Spillovers: How Much? How Important? Evidence from the International Banking Research Network

Claudia M. Buch and Linda Goldberg

NBER Working Paper No. 22874

December 2016

JEL No. F34,G01,G21

\begin{abstract}
The development of macroprudential policy tools has been one of the most significant changes in banking regulation in recent years. In this multi-study initiative of the International Banking Research Network, researchers from fifteen central banks and two international organizations use micro-banking data in conjunction with a novel dataset of prudential instruments to study international spillovers of prudential policy changes and their effects on bank lending growth. The collective analysis has three main findings. First, the effects of prudential instruments sometimes spill over borders through bank lending. Second, international spillovers vary across prudential instruments and are heterogeneous across banks. Bank-specific factors like balance sheet conditions and business models drive the amplitude and direction of spillovers to lending growth rates. Third, the effects of international spillovers of prudential policy on loan growth rates have not been large on average. However, our results tend to underestimate the full effect by focusing on adjustment along the intensive margin and by analyzing a period in which relatively few countries implemented country-specific macroprudential policies.
\end{abstract}

Claudia M. Buch

Deutsche Bundesbank

Wilhelm-Epstein-Strasse 14

D-60431 Frankfurt am Main

Germany

claudia.buch@bundesbank.de

Linda Goldberg

Federal Reserve Bank-New York

33 Liberty Street

New York, NY 10045

and NBER

linda.goldberg@ny.frb.org 


\section{Introduction}

The development of macroprudential policy tools is one of the most significant policy changes in the past decade. Macroprudential policies aim at mitigating systemic risks in financial markets. Macroprudential tools are often explicitly applied to banks and are mostly implemented at the national level. Examples of such tools are bank capital requirements, counterparty concentration limits, interbank exposure limits, loan-to-value ratios, and reserve requirements. The desired targets might be bank lending growth, the resilience of banks to shocks, or asset markets that are deemed to be frothy or mispriced.

The effectiveness of these tools is a key consideration. Analysis of early experiences with macroprudential instruments shows that some tools can reduce banks' asset growth within countries (Claessens, Ghosh, and Mihet 2014). However, effectiveness may be weakened when risky or excessive lending moves outside of the regulatory perimeter to non-covered entities or activities (Bengui and Bianchi 2014; Aiyar, Calomiris, and Wieladek 2014; Reinhardt and Sowerbutts 2015) or to other geographic regions (Houston, Lin, and Ma 2012).

The international financial openness of countries and the global nature of financial institutions present added challenges (Obstfeld 2014). ${ }^{1}$ International spillovers through banks matter for instrument effectiveness within a country's borders and are relevant for the broader issues of policy frameworks, externalities, reciprocity, and welfare. Yet, there is little systematic evidence that establishes whether spillovers are common, important, and support or hinder the attainment of policy goals. The gap in knowledge is particularly acute when it comes to evidence drawn from and relevant for a broad range of countries. Providing this evidence on prudential policy effects and international spillovers is the subject of this multi-study initiative of the International Banking Research Network (IBRN). ${ }^{2} 15$ country teams examine domestic effects and international spillovers of prudential instruments using detailed confidential micro-banking data. In addition, researchers from the Bank for International Settlements (BIS) and from the European Central Bank (ECB) provide cross-country perspectives. The analyses focus on evidence for international policy spillovers through multiple channels: Inward transmission

1 For a more detailed discussion of macroprudential toolkits, see Arregui et al. (2013), Claessens, Ghosh, and Mihet (2014), or Ostry et al. (2011).

2 The IBRN was founded in 2012 to analyze issues pertinent to internationally active banks. The current list of participating central banks and institutions is available at http://www.newyorkfed.org/IBRN/index.html. Most central bank teams have access to confidential bank-level data on domestic and cross-border banking activities. In a previous project, the IBRN analyzed the transmission of liquidity risk domestically and internationally through the activities of global banks, with a meta-analysis (Buch and Goldberg 2015) and eleven country studies published in the IMF Economic Review (November 2015). 
addresses how foreign regulations affect the domestic activities of domestic banks or foreign affiliates (bank branches or subsidiaries) located in the host country; Outward transmission to foreign economies addresses the effects of foreign policies on the foreign activities of a reporting country's global banks. All country teams implement the same baseline regression models for analyzing inward or outward transmission. In addition, country teams address issues specific to their banking markets or banks' business models. In some cases, teams differentiate adjustment of lending by their global banks' branches (which are subject to the capital requirements of their parents) versus subsidiaries (which are, in addition, subject to regulations in the host country).

This paper provides an overview of the full initiative, including its methodological and database contributions, and it presents a meta-analysis that generates key cross-country results. By design, the empirical studies we summarize are very homogenous because all teams used the same baseline regression model. Hence, publication biases that can affect metaanalyses that draw on only published research are not an issue here. Also, largely due to data availability, previous studies of international spillovers are more restricted as they consider fewer or less precisely dated policy instruments or countries, or as they cannot account for differences across banks or channels of policy transmission internationally. ${ }^{3}$

The IBRN has worked toward closing several gaps that have limited prior analyses. The IBRN provides cross-country evidence on regulatory spillovers using the same methodological framework and consistent data - both bank-specific and in terms of prudential instruments across countries. As researchers apply a common research methodology, the IBRN's broadly relevant insights go well beyond the single-country case studies. In order to identify effects of prudential policies, the project uses micro-data, and it exploits variation in prudential instruments across countries, bank balance sheet characteristics, and the location of foreign affiliates. Micro-data help in solving the identification problem which beleaguers impact assessment studies based on aggregate data. Identification using heterogeneity and in the international context is greatly aided by the degree of granularity of the data involved. To facilitate results which are comparable across countries, the IBRN and International Monetary Fund (IMF) developed a new database that contains more precise measures of prudential regulation than were available to prior researchers. Described in Cerutti, Correa, Fiorentino, and Segalla (2015), the quarterly database spans 64 countries and the period from 2000 to 2014. Most available studies cover the domestic consequences of domestic prudential policies. Examples include Bruno and Shin (2014), IMF (2011), Jiménez et al (2012) and Vandenbussche et al. (2015). 
The instruments covered include different types of prudential regulations: capital requirements, concentration limits, interbank exposure limits, loan-to-value ratio limits, and changes in reserve requirements. ${ }^{4}$

Based on the meta-analysis of 15 country studies and the findings of 2 cross country studies, here we highlight three key observations about prudential spillovers that are immediately of interest from analytical and policy perspectives.

First, some countries observe that prudential instruments spill over internationally and through banks via lending growth. Specifications that focus on international spillovers along the intensive margin and over a time horizon of several quarters detect significant international spillovers in about a third of the specifications. The baseline specifications provide a lower bound of regulatory spillover effects. As the analyses exclude large bank-specific outliers, they do not capture potentially large adjustments along the extensive margin, representing entry and withdrawal of banks from foreign markets. Moreover, as the meta-analysis summarizes results from a common empirical approach imposed across countries, the identified spillovers also exclude other potentially important country- and sector-specific dynamics that individual country analyses document.

Second, heterogeneity in spillovers through lending is common. This heterogeneity is at the bank-level, where prudential instrument effects on lending can each differ with the balance sheet characteristics and business models of the banks participating in international lending. For example, foreign affiliates with higher illiquid asset shares and with stronger reliance on deposit funding tend to have loan growth that responds more to loan-to-value ratio limits and sectorspecific capital buffer changes in the foreign parent location. Degrees of internal liquidity management via internal capital markets can matter too, significantly differentiating across these hosted affiliates in terms of how general capital requirements imposed in the parent's country spill over into lending in the host market. These same characteristics do not appear to be as important for the inward transmission of foreign policies into the domestic lending of global banks.

4 To construct this database, the IBRN and IMF collaboratively worked with regulatory sources in the individual countries, and extended and utilized the Global Macro Prudential Instruments (GMPI) survey which the IMF conducted in 2013. Note that stress tests, which may give incentives for banks to adjust their foreign exposures, are not covered in this project. Changes in reserve requirements are included as they are sometimes used explicitly by countries for prudential purposes, instead of as monetary policy instruments. 
Cyclical considerations do not appear as important for the spillovers of regulations to international lending activity. Most countries do not find strong evidence that international spillovers of prudential policy differ across the business or financial cycle.

Third, the economic magnitudes of international spillovers of policy thus far have not been large on average. However, the pattern of results highlights the potential for larger and more consequential spillovers as the use of macroprudential instruments increases. Changes in capital requirements, for instance, have largely been implemented in many countries during similar time frames, potentially limiting some of the first mover advantages for countries that had banks with higher initial capital ratios. Even with this limitation, in some cases, banks with higher initial capital were poised to increase lending internationally, sometimes pivoting from domestic loan growth, when foreign countries tightened their capital requirements. Changes in some prudential instruments may thus spur market share repositioning across banks and foreign countries.

Overall, based on the evidence provided from a range of country experiences with international spillovers of prudential instruments through bank lending growth, we conclude that there is not a one-size-fits-all channel or even direction of transmission that dominates spillovers. While most of the countries in the IBRN initiative are advanced economies, we do not observe that results are systematically different between these countries and participating emerging market countries. Simple arguments about regulatory arbitrage do not characterize the diversity of experiences across countries. Almost all prudential instruments have been associated with both positive and negative spillovers, within and across transmission channels. The effects through specific banking institutions can depend on their balance sheet characteristics and business models. All of these observations raise complex questions: How can countries insulate themselves from international spillover?; Are there tradeoffs between microand macroprudential policy?; What if the goals of macroprudential instruments are made more difficult to attain if, at the same time, the microprudential conditions locally are changing with the market share adjustments across domestic and foreign banks?; What might policy reciprocity achieve?

The rest of this paper is organized as follows. Related literature and conceptual arguments are presented in Section 2, and hypothesis testing and empirical models are in Section 3. Data are discussed in Section 4, with more detail in Appendix B. Key findings are in Section 5, both through a meta-analysis study of the patterns of international spillovers identified in the baseline empirical models explored by 15 countries and through highlighting the idiosyncratic specifications run by countries. Section 6 provides a short summary of results. 


\section{Prudential Spillovers: What do we Know? What do we Expect?}

The terms "regulatory arbitrage", "leakages", and "spillovers" are sometimes used interchangeably. All three terms have been invoked to describe when regulations in one market have consequences for other markets or other institutions. But spillovers do not necessarily reflect regulatory arbitrage or policy leakages. Spillovers can occur as a natural response to changing supply or demand for credit in particular locations and by particular institutions. As spillovers have less of a loaded connotation than "leakages," we use this language. In general, we cannot identify whether banks adjust to regulations in an intentional way with the explicit aim to circumvent regulation or whether policy is ineffective because global banks adjust their international activities. In describing the prior literature and moving forward with the exposition of the IBRN initiative we apply our broad definition to comprise the respective concepts. In general we analyze the effects of particular policy instruments, for example loan to value ratios or capital requirements, to inform the consequences of prudential policy.

\subsection{Prior Empirical Studies}

Previous empirical studies of prudential instrument effects either follow a cross-country approach, for example using BIS International Banking Statistics combined with a cross-country database on regulations, or focus on the effects of prudential instruments for a specific country. Most studies focus on domestic effects of instruments within the country applying the regulatory changes.

Using detailed data on prudential instruments similar to that within the IBRN database, other studies provide cross-country lessons for domestic macro-economic and financial sector aggregates. A number of studies use aggregate credit data. IMF (2011) use a 2010 survey on the use of macroprudential instruments for 49 countries and find that most macroprudential instruments (DTI, LTV, dynamic provisioning, reserve requirements, and credit growth ceilings) are effective at reducing the cyclicality of credit growth, but that this effectiveness is sensitive to the type of shock considered. Akinci and Olmstead-Rumsey (2015) use data covering 2000-2013 of changes in macroprudential policy instruments affecting the housing market such as loan-tovalue ratios (LTVS) and debt-service-to-income (DTI) ratios. They find that overall real domestic bank credit declines if prudential measures are tightened. Mortgage lending and house prices are affected only by macroprudential instruments related to the housing market. Kuttner and Shim (2013) find a similar result in that only DTI significantly affect housing credit growth. Bruno, Shim, and Shin (2015) document the role of macroprudential policies and capital controls in mitigating credit growth in 12 Asian economies. 
Cerutti et al. (2015) use the 2013 GMPI IMF survey to create a database of macroprudential policy stances in 119 countries, and find that domestic credit growth in emerging markets is weaker when prudential policy stances are more restrictive. They also find that macroprudential instrument effects are weaker in countries which are more open, suggesting evidence of leakages.

Claessens et al. (2014) are the only authors to use bank data rather than aggregate credit. They use annual data collected through an internal IMF survey of country desk economists and a sample of banks in 35 countries over the years 2000 to 2010 and find that caps on certain activities - and particularly measures aimed at borrowers - may have a stronger impact on banks' asset growth than general capital buffers. The effectiveness of these tools was not found to vary by the intensity of the credit cycle.

Several studies look at prudential policy leakages from the perspective of a specific country and focus on domestic lending. Aiyar, Calomiris, and Wieladek (2014) focus on the leakages that arise when an instrument covers domestic banks, but is not applied to the branches of foreign banks operating in the domestic market. The study concludes that leakages weaken policy effectiveness in the U.K. Aiyar, Calomiris, Hooley, Korniyenko and Wieladek (2014) exploit exogenous changes in the capital ratios of U.K. banks to investigate whether these regulatory shocks are transmitted abroad. As the regulatory changes were imposed at the unconsolidated level, the authors argue that cross-border lending responds more than lending by affiliates abroad.

After the financial crisis, some global banks have retrenched from foreign markets. There is hardly consistent cross-country evidence analyzing the drivers of this retrenchment. One prudential policy database commonly used in previous studies and compiled by Barth, Caprio, and Levine (2013) has indices constructed based on survey responses to reflect the broad stance of regulation and supervision. The three-year survey intervals are not ideal for studies using higher frequency data and focusing on the identification and assignment of effects to particular instruments. Houston, Lin, and Ma (2012) use these data and find that banks lend more in markets with fewer regulations when there is an effort by domestic regulators to limit bank risktaking. Bremus and Fratzscher (2015) combine these data with the BIS international banking data and show that cross-border bank outflows appear to be driven by expansionary monetary policies, with some flows mitigated by tighter regulation. Reinhardt and Sowerbutts (2015) construct a database of macroprudential instruments for sixty countries and find that countries increase aggregate borrowing from abroad after an increase in capital requirements but not after an increase in lending standards, attributing these outcomes to the coverage of these instruments. As we observe in our initiative and discuss in Section 5, some of the specific 
dynamics in global bank reactions to policy instruments depend on their ex ante balance conditions, which are not generally observable or used in studies of aggregate data.

\subsection{Expected Effects of Specific Instruments}

Previous work reviewed above provides a mixed picture of the effects of prudential instruments. While most studies find a decline in domestic lending following a domestic regulatory tightening, effects differ across banks, countries, and instruments. In terms of international spillovers, no single theoretical model captures the range of possible international transmission channels and bank-level responses to the different prudential policy instruments capital requirements, exposure limits, concentration limits, loan-to-value ratio limits, and minimum reserve requirements - examined by teams participating in the IBRN initiative. Figure 1 details possible routes for inward and outward policy transmission, whether through global banks directly or through their affiliates around the world.

To illustrate the distinct channels of outward and inward policy transmission internationally, consider a global bank from the United States (U.S.) which owns an affiliated bank in Germany and another in the United Kingdom (U.K.). Suppose that the affiliate within Germany lends only in that host country, while the U.K. affiliate lends both in the U.K. and elsewhere throughout Europe. The global bank can move funds across both affiliates and its U.S. operations as part of a consolidated operational strategy. The bank's lending in Germany could depend on U.S. regulations, German regulations, and on regulations in the U.K. If the U.K. implements a prudential policy change and this influences U.S. bank lending in the U.K. and possibly Germany, we refer to this adjustment as the outward transmission channel. ${ }^{5}$ If the U.K. prudential policy influences lending by the U.S. bank in its home (U.S.) market, this is an inward transmission channel.

As an example of expected effects consider the possible implications of capital requirements in the domestic market. In the longer-term, higher capital requirements make bank lending less cyclical, albeit at a marginally lower level. In the short-run, the costs of raising capital may be high and banks at home may reduce the supply of credit if capital constraints become more binding. This response should be related to bank-specific capital ratios and overall balance sheet composition in terms of risks and funding structures. The response will also differ whether the capital requirement is set at the consolidated level or whether it applies to a particular domestic sector (SCR) - in which case there may be a relative price effect when lending abroad. Some

\footnotetext{
5 Alternatively, there could be an outward reallocation between the U.K., Germany, and other foreign markets.
} 
domestic banks may increase international activities by moving to less regulated markets if the regulation does not bind or is not applied on a consolidated level. Alternatively, tighter regulations may induce banks to lower their foreign market activities if their global balance sheet constraints become more binding. How domestic banks are affected by regulatory policies will thus depend not only on how the policy is applied but also on the strength of their balance sheet and on their international business model. The response of foreign banks to the domestic regulation can depend on their own relative capital position and profitability. For example, if the foreign banks start out with a relatively strong capital position, they can be well situated to expand lending in a location where the domestic banks have retracted loan supply due to tighter standards. These foreign banks may respond differently if their affiliates in the domestic market are subsidiaries that are subject to the tighter capital requirements, instead of affiliates established as overseas branches which are not.

The effects of tighter capital requirements may also change over time as banks can raise additional external equity or retain profits. Any negative impact effect might thus be mitigated over time, and capital requirements become less binding. Careful analysis of the timing of effects is warranted. Capital regulations are more likely to bind when the cost of raising equity is high, in other words at the bottom of the output and financial cycles, when profitable opportunities are rare and capital markets are less exuberant. Another noteworthy feature of changes in capital requirements is that many have been implemented following international agreements. As such, their impact is likely to be more global than the effects of prudential regulations for which there is more national discretion with regard to implementation. At the same time, spillover effects might be more limited to the extent that changes in regulation are coordinated internationally and applied at the consolidated level.

Consider next the mechanisms for international spillovers from changes in loan-to-value ratios which limit the amount of borrowing a debtor can have on a particular transaction as a fraction of the underlying asset value. Use of these instruments is typically not coordinated internationally. Such limits work on credit demand rather than credit supply, and studies such as Claessens, Ghosh, and Mihet (2014) have concluded that these instruments may be most impactful on credit outcomes. A priori, international spillovers may be weaker and banksspecific characteristics, such as the degree of capitalization, may be less relevant for identifying the effects of these instruments. If a foreign country changes LTV caps on mortgage lending, there may be a limited inward spillover if domestic credit demand is unchanged. However, LTV limits also limit the risk that a bank is able to take in its home market. Hence, banks affected by the regulation might change the composition of their credit supply by substituting away from mortgage lending at home toward lending into other sectors or internationally. 
Reserve requirements or interbank exposure limits are instruments which may induce spillovers as these instruments serve as funding restrictions. ${ }^{6}$ Generally, higher reserve requirements make either domestic currency deposits or foreign currency deposits scarcer depending on the specific application of this instrument. With higher reserve requirements in place, the cost of funding rises. Banks cannot lever up this funding to the same degree as previously, thus favoring other sources of funding. The return offered to depositors would be lower, which may reduce funding and lending. Restrictions on interbank exposures can lead to spillovers from or to banking systems and possibly have concentrated effects on banks that depend more on interbank funding. For global banks, restrictions also may constrain the scale of borrowing from related parties through internal capital markets, generating funding reallocations.

The IBRN analysis of international spillovers does not consider the reasons why policymakers vary prudential instruments. Macroprudential policies differ in intent from microprudential policies which aim at stabilizing individual financial institutions, differ from capital controls which target the cross-border movement of capital, and differ from monetary policy which targets a combination of macroeconomic goals such as low price inflation and full employment. ${ }^{7}$ We focus on the prudential policy changes more broadly, regardless of whether stated as explicitly macroprudential or microprudential. Changes in interbank exposure limits may be triggered by microprudential concerns, whereas changes in LTV caps typically aim at preventing an overheating of the housing market and thus have a macroprudential motivation. For example, a prudential policy instrument like exposure limits applied to banks is intended to reduce risks due to the concentration of lending on the balance sheets of the targeted institutions. This policy may be effective at achieving those goals for domestic entities, while at the same time other foreign institutions pick up the customers squeezed from those institutions for which the exposure limits bind. If the intent of policy was microprudential, such a redistribution of activity may be the desired outcome: demand for credit is satisfied by reallocating borrowers to institutions with stronger capital ratios and more liquid assets which may have more capacity to safely engage in domestic lending. However, if the policy was implemented for macroprudential reasons, the spillover might be less desirable and can be

6 Policymakers may tighten reserve requirements in order to dampen credit growth and thus have an (implicit or explicit) financial stability goal in mind. This may by the case, for example, if the legal basis for the use of other macroprudential instruments is inadequate or if the institutional mechanisms to activate those instruments are comparatively restrictive.

7 See the discussions of the standard Tinbergen assignment problem by Fischer (2010) and Obstfeld (2014). 
interpreted as leakages that undermine the intent of the original policy. Likewise, if exposure limits constrain lending to particular domestic counterparts, institutions might shift activity to other economies or those counterparties unconstrained by the exposure limits. Such spillovers may not be attempts to circumvent regulation or even leakages, but instead are a result of an intended reallocation of bank activities.

\section{Hypothesis Testing and Empirical Models}

Fifteen IBRN country teams, as well as cross-country studies conducted by the BIS and ECB, examine whether bank lending responds to changes in prudential regulation, and whether these responses are shaped by characteristics of the banks or the state of the financial cycle. ${ }^{8}$ For both dimensions - the lending response and the prudential instruments - we consider the home and the foreign markets. From Figure 1, we consider four types of banks for each country pair ij: Domestic banks in $i$ that operate in $i$ and not in $j$ (but may lend cross border); domestic banks in $i$ that have affiliates in $j$; banks headquartered in $j$ that have affiliates in $i$; and banks that operate in $j$ and $i$ but headquartered in $k$. While the specific features of the data in the inward and outward transmission exercises determine some modelling choices, a number of specification features pertain to all models. In the methodological discussion we focus specifically on the common empirical methods applied by country.

\subsection{General Specification Features}

\subsubsection{Dependent Variables}

Bank lending as the key transmission channel running from banks to the real economy is the dependent variable. Using changes in loans as the dependent variable has the added advantage that loan data are readily available and relatively comparable across banks and countries. These data will be considered in comparable baseline specifications implemented by all country teams. The observations on the loan data accord with the perspective of the specification

8 The studies included in this IBRN initiative on the impact of prudential instrument changes on the activities of global banks include: Auer, Ganarin, and Towbin (2016) for Switzerland; Avdjiev, Koch, Mcguire, and von Peter(2016) using international data; Berrospide, Correa, Goldberg, and Niepmann (2016) for the US; Başkaya, Binici, and Kenç (2016) for Turkey; Bonfim and Costa (2016) for Portugal; Bussière, Schmidt, and Vinas (2016) for France; Caccavaio, Carpinelli, and Marinelli (2016) for Italy; Damar and Mordel (2016) for Canada; Frost, de Haan, and van Horen (2016) for the Netherlands; Gajewski and Krzesicki (2016) for Poland; Hills, Reinhardt, Sowerbutts, and Wieladek (2016) for the UK; Ho, Wong, and Tan (2016) for Hong Kong; Jara and Cabezas (2016) for Chile; Levin, López, López-Gallo, and Martínez (2016); Nocciola and Żochowski (2016) using international data; Ohls, Pramor, and Tonzer (2016) for Germany; and Park and Lee (2016) for Korea. 
studied by the researcher, so may represent domestic loans, cross-border loans, or local claims. If available, in their respective additional analysis some country teams have also used claims and more refined sectoral breakdowns of loans. ${ }^{9}$

Because we are interested in the responses of lending to changes in prudential instruments, the baseline model uses log changes in stocks as the dependent variable. ${ }^{10}$ The advantage of using log changes is that the data are smoothed while conserving the ranking of the values. This approach implies that changes in prudential instruments may have temporary growth effects rather than permanent level effects, following the approach of Henry (2007) for changes in capital controls.

\section{$\underline{\text { 3.1.2 Prudential Instruments and Specifications }}$}

Prudential instruments could be introduced into the empirical specification simultaneously or individually, with lags, and as levels or in changes. Some instrument changes might have been implemented simultaneously, making it difficult to attribute possible effects to a specific instrument. Also, prudential instruments target different balance sheet items of banks and operate through different transmission channels. In the baseline model, instruments are included in separate specifications and in one additional specification that simultaneously includes all instruments. Moreover, teams examine spillovers using an index PruC that captures the change of any regulation and which is conceptually more comparable to the approach in studies that utilized the lower frequency (3-year survey) data of Barth, Caprio, and Levine.

The international dimension of prudential regulations is captured in four ways (Figure 1):

- Home (i.e. parent bank) country regulation $\left(\right.$ Home $\left._{\text {jt }}\right)$ : The home country is the country of the parent bank. For the outward transmission exercise, the home country is the country that conducts the study. Typically, regulation in the home country does not vary across banks. For the inward transmission case, the home country may vary across banks if the IBRN country hosts affiliates of foreign banks.

- Destination country regulation $\left(\right.$ Dest $\left.P_{\mathrm{jt}}\right)$ : The destination country is the economy to which a loan has been granted. This is mainly relevant for the outward transmission case. This

9 These data have been used in many previous studies. For details, see the International Banking Library, hosted at the Halle Institute for Economic Research (http://www.bankinglibrary.com).

10 In Appendix B, we describe the common methodology used for dealing with outliers. In addition, log changes of stocks do not inform about changes in loans relative to banks' balance sheets. Country teams thus use different scaling options in robustness exercises. 
economy does not need to be the host country of the bank because cross-border loans are considered as well, and those might be granted to third countries.

- Host country regulation $\left(\right.$ Host $\left.P_{\mathrm{jt}}\right)$ : The host country is the country where the affiliate of a bank is hosted. This is relevant mainly for the inward transmission case. In this case, the host country is the IBRN country that conducts the study. Recall that the destination and the host country might be different. In our previous example, a U.S. global bank owns a U.K. affiliate that lends to France and Germany. In this case, U.S. is the home, U.K. is the host country, and France is the destination country.

- Foreign exposure weighted regulation $\left(E x p P_{\mathrm{bt}}\right)$ : Banks can be subject to regulations in several countries, and teams create a composite measure of such regulations. In the outward transmission through global banks exercise, teams weight regulations with the foreign exposures outside the home country and destination countries. ${ }^{11}$ For the inward transmission case, domestic global banks that are active in several foreign countries are exposed to the regulations of those countries. Teams weight regulations with the bankspecific foreign exposures outside the home country. The exposure weights are based on exposures over the previous four quarters. They are calculated based on the sum of foreign assets (on an immediate borrower basis) and liabilities in a given market. ${ }^{12}$

The spillover effects of prudential policy should depend on whether policies are applied at a consolidated or unconsolidated level. Most of the home prudential policies apply to the consolidated entity, to domestic parents and their foreign branches (consolidated or unconsolidated). Foreign bank subsidiaries are generally subject to host-country regulations. Regarding the foreign affiliates in the home country, the same logic applies. The spillover effects also depend on the type of regulation. For example, capital regulation is likely applied on a consolidated basis to domestic banks and to the domestic subsidiaries of foreign banks. Other instruments, including reserve requirements, may only apply to specific entities within the organization. Moreover, sectoral capital requirements likely will be country-specific.

Tests for Inward spillovers of foreign policy instruments take two broad formats, depending on whether through global bank foreign exposures or through hosted affiliates of foreign banks.

11 These exposure weighted prudential instruments share some similarities with price indices in Melitz-type models (Melitz 2003), although we do not derive the indices from an explicit optimization problem. Note that the weights can be considered exogenous as long as the patterns of banks' international activities are sufficiently persistent and do not vary at the same frequency as the prudential instruments.

12 This summing of assets and liabilities follows the international trade and finance literature, in which openness to foreign trade is often measured through the sum of exports and imports (Leamer 1988). In some country cases, data availability constraints necessitate using variants of the recommended weighting approach. 
Tests of Outward spillovers of foreign policy instruments consider how global banks adjust total positions externally or how these global banks reallocate activity across foreign locations.

Formally, log changes in the stock of (domestic) loans $\left(\Delta Y_{b, t}\right)$ are linked to prudential changes, bank-level controls $\left(X_{b, t-1}\right)$, as well as bank- and time fixed effects $\left(f_{b}, f_{t}\right)$ :

$$
\begin{aligned}
\Delta Y_{b, t}= & \alpha_{0}+\left(\alpha_{1} P P_{b, t}+\alpha_{2} P P_{b, t-1}+\alpha_{3} P P_{b, t-2}\right)+a_{4} X_{b, t-1}+\left(\beta_{1} P P_{b, t} \cdot X_{b, t-1}+\beta_{2} P P_{b, t-1} .\right. \\
& \left.X_{b, t-1}+\beta_{3} P P_{b, t-2} \cdot X_{b, t-1}\right)+f_{b}+f_{t}+\epsilon_{b, t}
\end{aligned}
$$

where $P P_{b, t}$ is a policy measure appropriate for the international transmission exercise conducted. Time fixed effects capture changes in prudential instruments on the home market. Multiplying our interaction coefficients by the mean values of the corresponding balance sheet variables $\left(\bar{X}_{b, t-1}\right)$, the F-test $\sum_{i=1}^{3}\left(\alpha_{i}+\beta_{i} \cdot \bar{X}_{b, t-1}\right)=0$ considers whether the cumulative impact of regulations on lending growth over a time horizon of three quarters is statistically significant for the average bank.

An additional specification examined by teams allows for the effect of the foreign prudential instrument to vary over the home financial or business cycle. The resulting specification is

$$
\Delta Y_{b, t}=\alpha_{0}+\alpha_{1} P P_{c u m, b, t-1}+\alpha_{2} X_{b, t-1}+\alpha_{3} P P_{c u m, b, t-1} \cdot Z_{t}+f_{b}+f_{t}+\epsilon_{b, t}
$$

where $Z_{t}$ is the credit-to-GDP or output gap in the home market. In order to measure the effect of the financial cycle, we use a cumulative regulatory measure $\left(P P_{c u m, b, t-1}\right)$. Using mean values of our cycle variables $\left(\bar{Z}_{j, t}\right)$, prudential instrument net effects on lending growth for the average bank are analogously defined as $\left(\alpha_{1}+\alpha_{3} \cdot \bar{Z}_{j, t}\right)$ with a corresponding F-test of significance. Additional baseline specifications do not include interaction terms or include multiple prudential instruments simultaneously. A comprehensive discussion of the specific international transmission test and regression specifications is provided in Appendix A.

\section{$\underline{3.1 .3 \text { Identification }}$}

Identification of causal effects of policy instruments is helped by the use of micro- or bank-level data. The project exploits the joint effects of two features of the data to facilitate identifying effects of policy instruments.

This first identification feature is that prudential instrument changes are considered exogenous for the individual bank behavior, as opposed to aggregate credit measures, and in a cross-country environment. In this sense, our models take a partial equilibrium perspective: decisions on changes in prudential instruments are assumed to not be driven by the specific individual banks. But assuming this exogeneity is not sufficient. If all banks in the same country 
were to face the same prudential instrument changes, then instrument changes and common shocks could not be identified separately. Prudential variables would thus be tantamount to country-time effects. Our identification strategy depends on differences in prudential instruments affecting banks domiciled in the same country. These differences arise when banks are active in different countries and have heterogeneous exposures.

The second feature is that business models of banks are heterogeneous so that banks are expected to respond to the same policy measure in different ways. Some banks conduct crossborder activities, others maintain branches and subsidiaries, and borrowing and lending patterns are differently concentrated across countries. Adjustment along the extensive margin, with exit and entry from locations, is assumed to take place with a much lower frequency than changes in the lending and prudential policies.

\subsubsection{Other Specification Issues}

Whenever appropriate, country teams include within empirical specifications bank-, country-, and time-fixed effects to account for time-invariant heterogeneity at the bank- and countrylevel as well as common shocks affecting all banks in period $t$. As in Khwaja and Mian (2008), demand effects in country $j$ can be captured by introducing borrower-time fixed effects to account for changes in credit demand. ${ }^{13}$ While in the baseline specification clustering of residuals by country has been used, country teams have been advised to cluster as appropriate.

\section{Data and Descriptive Statistics}

Section 4.1 provides a high-level overview of the patterns of use and changes in prudential instruments over time and across countries included in the IBRN Prudential Instruments Database. Section 4.2 introduces the specifics of the bank-level balance sheet data examined by country teams. Section 4.3 provides details on the other variables used in the specifications, including credit cycles, output gaps, and country characteristics.

\subsection{Prudential Data}

The IBRN and the IMF collaboration, the Prudential Instruments Database, includes rich quarterly information on the announcement and implementation of policy changes for 2000 through 2014 for 64 countries, as described in in Cerutti, Correa, Fiorentino, and Segalla (2015).

13 Some papers follow a similar route but include country-time fixed effects instead. In this case, the country-level regulatory measure can be included in the interaction terms only. 
Seven prudential and regulatory instruments are included: general capital requirements, sector specific capital requirements (split into real estate credit, consumer credit, and other), interbank exposure limits, concentration limits, loan-to-value ratio limits, and reserve requirements (in local and in foreign currency). ${ }^{14}$ Generally, we do not explicitly distinguish whether prudential instruments have been activated for micro- or macroprudential reasons because the channels for generating cross-border spillovers are similar, regardless of the reason for instrument use.

For a tightening (loosening) of an instrument, the index is coded as $1(-1)$ in the quarter when a change in the policy takes effect. ${ }^{15}$ Indices are presented in two ways. The first type of index records the changes in each quarter when a policy is modified, with a zero in those quarters when no change occurs. The second type of index is a cumulative index. In each quarter, the index is the sum, since the first quarter of 2000, of all changes in that policy instrument recorded prior to and during the quarter of interest. The purpose of this cumulative index is to capture the level of overall "tightness" change of an instrument at a given point in time. If a particular instrument has never been introduced in a given country, the raw data are set to zero. While some of the prudential instruments have information on the overall level (tightness), this information is not used in the analysis of the IBRN initiative because of difficulties of constructing useful metrics similarly defined across countries and over time.

Table 1 provides insights into the variation observed in the full database, by prudential instrument, for the years 2000 through 2014. The table provides counts of the number of countries that report a change in each instrument, the number of overall changes in the instrument, and the breakdown between tightening $(>0)$ and loosening $(<0)$ events. The left panel of the table provides this information across all 64 countries in the database out of a total of 3,840 country-time observations; the right panel shows incidence across six countries Germany, France, Japan, Switzerland, United Kingdom, and United States - that have a number of large globally active banks. These countries are highlighted for their potential importance in generating international spillovers through prudential instrument changes.

(Table 1 here)

14 Information on capital controls is not included in the regulatory dataset. This information currently is not available on a quarterly basis, as in Schindler (2009) and follow up studies using the IMF's Annual Report on Exchange Arrangements and Exchange Restrictions. In the IBRN studies, differences in capital controls across countries or variations over time are assumed to be absorbed in the country and time fixed effects.

15 For some indexes, changes in a given quarter may be greater (lower) than 1 to account for the intensity in the change of the instrument that the index is capturing. For example, if a change in the reserve requirement in a quarter is double the change in the next quarter, this would be captured by a coding of 2 in the index for the first quarter and 1 in the second. 
Changes in general capital requirements and reserve requirements have been more relevant compared with changes in other instruments. For example, interbank exposure limits have been changed less frequently. In the right panel, only general capital requirements are well populated across these six countries and with multiple events; two countries changed reserve requirements on local currency deposits and two countries changed interbank exposure limits.

Time series variation in instruments also is important for the econometric exercise, since the instrument effects need to be separated from the time fixed effects used to control for omitted variables such as changes in aggregate demand. Instruments that have changes well distributed over time include concentration limits, loan-to-value ratios, reserve requirements, and sectorspecific capital requirements. Capital requirement changes are concentrated over time. Nonetheless, although international agreements such as Basel II or Basel III set a common framework for these regulations, there is still a sufficiently high degree of variability with regard to the implementation and activation of instruments across countries to perform meaningful analyses. $^{16}$

\subsection{Balance Sheet Data for Banks}

The data used by country teams is collected as part of financial supervision and regulatory reporting, with banks in each country providing confidential quarterly balance sheet data and data on international positions. The choice of bank-level characteristics in baseline empirical specifications is guided both by theoretical priors on which balance sheet and bank characteristics might matter for international transmission and by data availability.

The baseline specification's dependent variable $\left(Y_{b, t}\right)$ is based on total loan data for the reporting bank or global bank affiliate as relevant for the international spillover examined. The balance sheet characteristics $\left(X_{b, t-1}\right)$ included as explanatory variables capture the structure of banks' assets and liabilities, their profitability, and their degree of internationalization. Bank size is the log of total assets (LogTotalAssets ${ }_{b, t-1}$ ); liquidity is measured as the fraction of a bank's portfolio of assets that is illiquid (IlliquidAssetRatio ${ }_{b, t-1}$ ); the deposit ratio is the fraction of the banking organization's balance sheet financed with core deposits (CoreDeposits ${ }_{b, t-1}$ ); and the capital ratio is the banking organization's regulatory Tier 1 risk-based capital to asset ratio $\left(\right.$ Tier 1 Ratio $\left._{b, t-1}\right) .{ }^{17}$ The bank's degree of internationalization is generally measured through the

16 See Kalemli-Ozcan et al. (2013) for an overview of the timing of implementation of financial regulations across European countries.

17 Ratios are in percent (multiplied by 100). Some country teams use the balance sheet ratio of equity over total assets instead of regulatory Tier1 capital. 
difference between "net due to" and "net due from" of the Head Office as a measure of internal capital market positions of the entity, relative to assets (NetDueT $F_{b, t-1}$ ), and by foreign assets plus foreign liabilities, relative to total assets plus total liabilities (InternationalRatio ${ }_{b, t-1}$ ). More detailed information regarding data preparation, including variable definitions and cleaning procedures, may be found in Appendix $B$.

\subsection{Credit Cycles, Output Gaps, and other Country Characteristics}

To test for potential differences in prudential instrument effects over the (aggregate) credit cycle, some specifications include credit-to-GDP gap data. As in Drehmann, Borio, and Tsatsaronis (2011), the credit-to-GDP gap is defined as the difference of credit-to-GDP from its long-run trend in percentage points. ${ }^{18}$ The credit component draws on total credit to the nonfinancial private sector available at the BIS. ${ }^{19}$ If total credit is not available, data on domestic credit are taken from the IMF's International Financial Statistics. Financial cycles for the home country are included in the inward transmission models, and financial cycles for the host country are included in the outward transmission models. In addition, some specifications use domestic credit growth by country, with the time series on credit to the private non-financial sector available for a broader group of countries than the credit data, or output gap measures constructed following BIS methods (BIS 2014).

\section{Do Prudential Policies Affect International Bank Lending?}

Fifteen country teams studied a combination of inward and outward transmission exercises. Sections 5.1 and 5.2 summarize results only from the baseline models for inward and outward transmission implemented by countries. Individual country papers provide more detailed and nuanced analyses of inward and outward prudential policy transmission through bank lending. Cross-country analyses conducted by the BIS and ECB provide additional insights.

18 Prior studies show that financial cycles can be key indicators of emerging risks (Borio 2012; Claessens et al. 2011). As such, cyclical developments may ultimately be triggers for macroprudential policies such as the counter-cyclical capital buffer.

19 This long-run time trend in turn is calculated with a one-sided HP filter using a smoothing factor of 400,000. Data by country are available as the BIS' long series on credit to the private non-financial sector: http://www.bis.org/statistics/credtopriv.htm, http://www.bis.org/statistics/credtopriv/documentation.pdf. 


\subsection{Which Transmission Channels and Instruments have been Analyzed?}

The international spillover exercises explored by the country teams are summarized in Table 2 . Eleven of the fifteen countries study inward transmission of foreign prudential policy changes. Eight countries explore inward transmission through their own global banks that maintain foreign operations. Ten countries consider transmission into their country through the operations of the affiliates of hosted foreign banks. The next column shows that six of the fifteen countries study external adjustments in lending by their own global banks, i.e. the outward transmission channel. Among these, most specifications address the effects of foreign prudential policies on the external lending of global banks. A smaller number of specifications explore foreign lending reallocation through global banks via cross-border flows and foreign affiliates. As country teams focus only on those prudential instruments that show sufficient variation and on specific transmission channels, the total number of empirical specifications by channel thus differs across countries.

\section{(Table 2 here)}

\subsection{Meta-Analysis of the 15 Country Studies}

We perform a meta-analysis to extract relevant and robust lessons on international spillovers from the 15 country studies. Meta-analyses summarize the key outcomes of empirical exercises, and then explore which features of an empirical model are drivers of different empirical outcomes. A strength of the approach is that the empirical studies we summarize are designed to be homogenous, by using the same baseline regression model and variable definitions. Moreover, by summarizing the results of all the analyses, we are not subject to criticisms of publication biases that can affect meta-analyses that draw on only published research. By design, as we seek robust lessons on international spillovers we use conservative criteria for significance.

Our measure of statistical significance is the 10 percent significance of the summed effect on lending growth over linear combinations of all regression terms that include each specific prudential instrument. For example, in exercises that introduce prudential instrument interactions with bank-balance sheet characteristics, the relevant test result reported is over $\sum_{i=1}^{3}\left(\alpha_{i}+\beta_{i} \cdot \bar{X}_{b, t-1}\right)$ and $\left(\alpha_{1}+\beta_{1} \cdot \bar{X}_{b, t-1}\right)$, which utilizes the mean level of each balance sheet characteristic for the banking entities in each regression sample. In specifications in which there are interactions of the prudential instrument with business or financial cycles, the relevant metric for an effect on lending growth is the test result over the sum $\left(\alpha_{1}+\right.$

$\left.\alpha_{3} \cdot \bar{Z}_{j, t}\right)$ or $\left(\alpha_{1}+\alpha_{4} \cdot \bar{Z}_{j, t}\right)$. This type of test requiring the summed net effect of a prudential measure on lending is a more conservative threshold for significance compared with a test of 
statistical significance at any single quarter. As a conservative threshold, the exercise will tend to provide a lower bound on the incidence of international spillovers of prudential policies through bank lending. As exposited within the country papers, teams frequently observe statistically significant international spillovers when not netting over three quarters.

Table 3 shows the number of regression specifications and number of countries by prudential instrument and exercise that are used in the meta-analysis. The largest numbers of regression specifications across the collection of studies are for inward transmission of home prudential policies into host markets through hosted affiliates of global banks. Ten countries explore the spillover effects of changes in general capital requirements, sector specific capital buffers, loan-to-value ratios, and local reserve requirements. Fewer countries examine inward spillovers through hosted bank affiliates of the changes in foreign reserve requirements, interbank exposure limits, or concentration ratios. Eight countries examine inward transmission of foreign policies through the exposures of their own global banks. Six countries examine how their global banks reallocate lending internationally when foreign affiliate locations have changes in respective prudential instruments.

(Table 3 here)

\subsubsection{What is the Direction of Prudential Instrument Spillovers Through Global Banks?}

Table 4 considers the sign pattern of significant international spillovers, showing - by specific prudential instrument (rows) and by transmission channel - the share of empirical specifications that register: statistically insignificant spillovers (column a), positively signed significant spillovers (column b), and negatively signed significant spillovers (column c). "Positive" spillovers indicate that a tightening of a prudential measure in one location is associated with an increase in lending growth in another location. As baseline studies do not consider asymmetric effects of prudential policy tightening or loosening, the discussion of results assumes symmetry in spillovers even as the actual language of our discussion refers to tightening.

(Table 4 here)

Examination of Table 4 shows that the majority of these baseline regression specifications do not exhibit statistically significant international spillovers of prudential instruments. For example, when foreign general capital requirements are adjusted, the domestic lending of home global banks with affiliates in foreign locations does not significantly change in 75 percent of the specifications examined across country teams. However, significant international 
spillovers of this instrument are still often observed. ${ }^{20}$ In 25 percent of the specifications covering home global banks, when foreign capital requirements tighten these banks significantly increase domestic lending growth in 19 percent of cases (column b) and reduce domestic loan growth in the remaining 6 percent of cases (column c). Similar patterns are observed in the outward spillovers of these policies.

The last columns of Table 4 show that global banks reallocate lending externally when local reserve requirements change. Foreign reserve requirement tightening on local deposits is more often associated with global bank expansion of lending growth abroad than with lending growth contractions. While the literature reviewed in Section 2.1 tended to find that lending declines when regulations tighten, this evidence drawn from a broad sample of countries using microbanking data shows a mixed pattern of responses to most policy instruments. Interestingly, the columns summarizing inward transmission of policy through hosted affiliates of foreign banks show that general capital requirements are least likely to be associated with significant inward lending transmission, while home reserve requirements, LTV caps, and concentration limits have significant spillovers into host loan growth in one quarter to one third of the regression specifications.

Table 5 complements these results by showing which countries' experiences drive the patterns of significant instrument spillovers just described. When foreign countries tightened general capital requirements, positive spillovers to home loan growth by global banks were observed across U.S., German, and Chilean banks, while German global banks had significantly reduced loan growth outwardly and US global banks had mixed directional effects depending on the regression specification. Negative inward spillovers were observed for U.K. and Swiss global banks. The German global banks also expanded home loan growth when foreign loan-to-value limits tightened, without significant outward transmission from the LTV ratios. Tighter local reserve requirements influenced outward transmission by global banks in in all of the countries which studied this channel. Global banks from Canada, France, Italy and the Netherlands increased lending growth externally, while U.S. and German banks contracted loan growth abroad without increasing loan growth back home. This directional heterogeneity, with the incidence differing across instruments and transmission channels, is important for understanding the intended and unintended effects for a range of prudential instruments.

(Table 5 here)

\footnotetext{
${ }^{20}$ This significance is beyond the level that likely could be attributed to Type I errors: under the hypothesis of "no spillovers" about 10 percent of specifications are expected to be significant at the 10 percent level.
} 
All country teams tested to see whether bank-level balance sheet characteristics were important drivers of identified heterogeneity in the international spillovers through the respective channels. Table 6 summarizes which countries identified a significant role for particular balance sheet characteristics. In inward transmission of general capital requirements by global banks into domestic loan growth, core deposit ratios of banks were important for four countries; net due ratios and Tier 1 capital ratios were important features in transmission through hosted affiliates of foreign banks. Within a country, heterogeneity in loan growth spillovers from the loan-to-value ratio changes in the home countries of hosted foreign bank were often associated with bank-specific illiquid asset ratios, asset size and core deposit ratios. Tier 1 capital ratios also differentiated global banks in the spillover of exposure-weighted reserve requirements on foreign deposits and concentration ratios into domestic lending growth. Overall, these findings are consistent with the prior that a tightening of prudential regulations induces a reallocation of market shares away from weaker banks towards banks with stronger balance sheets. Changes of prudential instruments therefore are observed to have influence on the global pattern of international lending, with potential implications for competition, bank-level risk, and financial stability.

(Table 6 here)

\subsubsection{Which Specification Features Drive the Likelihood of Observing International Spillovers?}

As a complement to these summary tables, we perform a formal meta-analysis using Probit regressions to explore which spillover regression features and data sample characteristics are associated with a higher or lower likelihood of significant international spillovers for each prudential instrument. These Probit regressions consider whether the likelihood of identifying a significant spillover varies across advanced and emerging markets, ${ }^{21}$ across the type of prudential transmission exercise (inward spillovers through hosted affiliates versus through global banks, versus outward through global banks), across specifications that: include only recent changes in prudential instruments versus including cumulative changes; or across transmission specifications that include versus exclude bank-specific balance sheet characteristics, that control for financial and business cycles, or that simultaneously introduce the effects of multiple prudential instruments. ${ }^{22}$ The dummy variable is $P P^{*}$ bank for models

21 An emerging market dummy captures potential differences in spillovers between emerging market and advanced economies, although emerging markets only explored inward transmission exercises.

22 A dummy indicating whether all prudential instruments are included in the specification simultaneously, versus one at a time, is potentially important as the simultaneous instrument specifications reduce the degrees of 
with interactions between the prudential policy instrument and bank-specific balance sheet characteristics, and $P P^{*}$ cycle for models with interactions with cycle indicators and including cumulative policy changes. Finally, the specifications include a continuous variable reflecting the percent of instrument changes that represent tightenings as opposed to loosenings; and include the share of foreign banks in the banking system studied, which may matter for the aggregated transmission of spillovers through foreign banks and for market share considerations. The dummy variables are further described in Appendix B.2.

Each row of Table 7 represents an individual Probit regression. ${ }^{23}$ Three Probit regressions are presented for each prudential instrument. The "all" row has the dependent variable take the value of 1 if a specification reported by a country team indicates a statistically significant international spillover of the prudential instrument, where significance is defined as summed over three quarters and at the 10 percent level. The "positive" row keeps a value of 1 only if the prudential instrument tightening is associated with spillovers of stronger loan growth externally. The "negative" row explores whether prudential instrument tightening is associated with reduced international loan growth. The columns of the table show the roles of the respective specification or country characteristics in differentiating the probability of significance relative to the base case of the Probit. The base case is the probability of a significant effect of the prudential instrument on lending growth for an advanced economy through hosted affiliates of foreign banks, in a specification that includes only one prudential instrument and without cycle or bank-characteristic interactions. The rightmost columns of Table 7 provide the total number of regression observations by instrument and the Pseudo $R^{2}$ of the specification. The Pseudo $R^{2}$ indicates the relative power of the full group of right-hand side variables in describing the pattern of observed significant spillovers of the respective prudential instruments into lending.

(Table 7 here)

From Table 7, observe that countries classified as emerging markets (Mexico, Poland, Chile, Turkey) have a lower probability of significant inward transmission of foreign prudential policies, except for inward spillovers of interbank exposure limits and concentration ratios where the

freedom in the regressions and may raise the difficult of identifying a significant set of regression coefficients. However, such specifications avoid omitted variable bias that might occur when prudential instruments are changed by a country at the same time, potentially causing a single instrument to mistakenly pick up the effect of another instrument not included.

23 While Table 7 compares Probits on any significance versus by sign of significance, other Probits have been explored using different weighting approaches applied to regression observations (for example country weights, banking system size weights). Results are available on request. 
probability is higher. For these latter two instruments, inward transmission through hosted foreign affiliates is more likely to be associated with spillovers compared with through global banks. The columns for inward transmission through global banks and for outward transmission together show that the probability of tighter general capital requirements being associated with higher international lending growth is greater for global banks compared with through hosted foreign affiliates. Global banks are more likely to be associated with declines in loan growth internationally from foreign tightening of loan-to-value limits and concentration ratio limits.

The table column for the PP* cycle indicator shows that this variable is usually insignificant or significant and negative in sign. The interpretation of this finding is that country teams did not have a higher probability of finding significant international spillovers in specifications that consider cumulative tightening or loosening of instruments, or in which these effects were interacted with the state of the financial cycle or business cycle. This is an interesting result, as prudential limits might be expected to bind more and spillover to a greater degree at times when the banks are more extended through the financial cycle. Of course, as the sample period of the underlying analysis in general was short (2000 through 2014), increased experience with prudential instruments over multiple cycles would make this observation more robust.

The table column for the $P P^{*}$ bank indicator considers whether the specifications that include interactions between prudential measures and bank-specific balance sheet characteristics have higher or lower probability of finding significant international spillovers. While it was observed (Table 6) that bank-specific balance sheet characteristics are important in the cross-sectional responses of banks to prudential instrument changes, in general such characteristics did not raise the probability of finding international spillovers. This inclusion reduces the degrees of freedom in the regressions and may raise the difficulty of identifying a significant set of regression coefficients, possibly explaining some of the negative coefficients observed in the associated column within Table 7. The specifications that simultaneously include all prudential instruments, indicated by All PP, likewise can reduce the degrees of freedom in the regressions while helping identify the role of a particular instrument, especially when other instruments have also been changing and could elicit the international spillovers. This type of specification increases the probability of finding significant spillovers from concentration ratios, and lowers the probability of some of the specific directional findings from other instruments.

Finally, the Probits consider whether those regression specifications that had more unidirectional changes in direction for an instrument were more likely to be able to identify the international spillovers from that instrument. This finding is supported in the case of general and sector-specific capital requirements, and for foreign reserve requirements. Foreign 
ownership share in the local banking system, the last column of the table, did not systematically change the direction or likelihood of spillovers in some robust way across all prudential instruments.

\subsection{What Other Broad Observations Arise from the IBRN Studies?}

So far, we have summarized results from the baseline regression that were designed for maximal comparability across countries and the meta-analysis. These key findings are set against a high threshold for identifying consistent effects across transmission exercises. The common baseline model did not consider the specificities that were clearly identified in more idiosyncratic explorations present in the broader range of country studies of the full IBRN iniative. Beyond these baselines, individual country papers and cross-country papers (without micro-banking data) provide more in depth and nuanced analyses that generate additional insights on international spillovers of prudential instruments. While the reader is referred to those studies, here we highlight examples of some additional findings from across those papers.

Two countries - Germany and the U.S. - analyze both inward and outward transmission of prudential policies through loan growth of global banks, and contrast inward transmission through domestic global banks and hosted foreign affiliates (Berrospide, Correa, Goldberg, and Niepmann 2016; Ohls, Pramor, and Tonzer 2016). When foreign capital requirements tightened, in both cases global banks expanded loan growth at home. German global banks tended to contract loan growth externally, while U.S. bank directions of outward transmission depended on the regression specifications studied. Interestingly, neither the U.S. nor Germany experienced significant changes in domestic lending by their hosted affiliates of related foreign banks when parent country capital requirements tightened. Global banks from both countries contracted foreign loan growth in localities that raised local reserve requirements, while not changing lending back at home. Foreign changes in loan to value ratios and concentrations ratios did not lead to significant outward retrenchment in loan growth by the respective global banks.

A few of the country studies suggest that market share repositioning across global and domestic banks may be a significant implication of prudential instruments changes. The outward transmission channel analyzed by Canada, France, Italy, and the Netherlands confirms a positive prudential spillover effect: as prudential instruments tightened, foreign lending growth tended to increase (Bussière, Schmidt, and Vinas 2016; Caccavaio, Carpinelli, and Marinelli 2016; Damar and Mordel 2016; Frost, de Haan, and van Horen 2016). This finding is consistent with foreign banks acquiring market share during a country's tightening episode, either because they are not directly affected by the tighter regulations or because the 
regulations are less binding. For example, well-capitalized banks may have been poised to expand their international presence when other countries increased capital ratios and constrained the activities of their own local firms. Some of the positioning and tendencies might be sensitive to the organizational form of country global bank exposures to foreign locations.

German and Italian teams also explored differences in prudential spillover responses across branches versus subsidiaries of foreign banks. Outward lending by hosted subsidiaries of foreign banks in Germany was rather unresponsive to changes in prudential instruments affecting parent banks, whereas cross-border lending and lending by hosted branches reacted more strongly to changes in regulations. In the case of Italy, inward transmission through hosted branches was observed specifically in response to changes in local reserve requirements and sector-specific capital buffers.

Some of the studies by teams also underscore how the unit of observation - total loans - of the baseline work used in the meta-analysis is likely to understate some important international spillovers of prudential policies. For example, results for the United Kingdom emphasize the importance of using sectorally disaggregated data (Hills et al. 2016). As an illustration, tightening in LTV ratios in the home market of parents outside the U.K. leads to an increase in lending to private non-financials and households in the U.K. When the home country tightens foreign reserve requirements, lending to both financials and private non-financials decreases.

Other considerations that are potentially important for detecting significant spillovers are other policy measures such as capital controls, more of a focus on regional linkages, and asymmetric effects of tighter or looser policies. In Korea, inward spillover effects were viewed as relatively weak because foreign banks are not very active on the retail market and because regulations of cross-border capital flows matter (Park and Lee 2016). Accounting for the intensity of bilateral linkages by, for example, using weighted regressions was found to be a better measure of the economic effects of spillovers in the study by Mexico. When the main banks from the U.S. and Canada were explored, the Mexico analysis picked up more significant spillovers of prudential policies into domestic retail lending (Levin et al. 2016).

The econometric methods that assume the tightening and loosening episodes have symmetric effects on loan growth may be inappropriate in the future for some instruments. Symmetric effects would not be expected for instruments like capital requirements, which were exclusively tightening episodes in the period studied, or sector specific capital buffers, which exhibited both tightening and loosening episodes. When Netherlands considered such asymmetries, they concluded that Dutch banks increased lending in countries that tightened prudential regulation and decreased lending when regulation is relaxed, but to different 
degrees. The effects were more significant in larger banks, in lending to advanced economies, and in the post-crisis period.

Reinforcing how the common empirical approach will not pick up all potential international spillovers, the U.S. also provided a difference-in-difference analysis of the international lending done by two types of U.S. global banks: those banks subject to or not subject to the Comprehensive Capital Analysis and Review (CCAR). This type of review was applied to systemically important institutions. The loan growth comparison across global banks showed that the affected banks subject to enhanced capital analysis reduced loan growth to foreign residents relative to the loan growth of the comparison group. The magnitude of difference in loan growth effects depended on the balance sheet characteristics of the banks, again reinforcing our broader observation of heterogeneity in the effects of prudential instruments across banks, and vis-à-vis international counterparties.

An additional scope for international spillovers of prudential instruments comes from expanding the analysis beyond just the lending of banks, and taking into account the funding side of bank balance sheets. Turkey finds that prudential spillovers occur both on lending and borrowing (Başkaya et al. 2016): prudential tightening abroad led to higher cross-border borrowing by banks in Turkey for the case of lower LTV limits.

Finally, while the individual country studies provide many advantages in terms of identification of effects and heterogeneity of responses to prudential instruments, they do not provide a full view of the reallocation of international financial flows through banks in response to prudential policies. This latter goal is accomplished in the cross-country analysis using country aggregates by Avdjiev, Koch, McGuire, and von Peter (2016) from the BIS, which uses panel data for banks from 16 home countries active in 53 destination countries. Among the seven instruments analyzed, loan-to-value limits and local currency reserve requirements have the most significant impact on international bank lending. The estimated international spillovers of the prudential tightening tend to be positive, so that tightening in one country is more likely to be associated with expanded loan growth elsewhere. Analysis of cross-country propogation in the euro area through 248 banks from 16 euro area countries by Nocciola, Zochowski, and Franch (2016) of the ECB conclude that inward spillovers of foreign prudential policies were present. Generally, instruments directed to specific borrowers, such as loan-to-value limits or sector specific requirements were most prone to spillovers, while the tightening of capital requirements tended to be associated with a decrease in lending.

Balance sheet characteristics of banking systems sometimes influenced the magnitudes of spillovers. Consistent with the country studies that suggested the potential for market share 
reallocations in response to changes in prudential regulations, the BIS team cross-country work found that better capitalized banking systems, those with more liquid assets, and those less reliant on core deposit funding had stronger loan growth externally when prudential instruments were more restricted at home, for example from tighter loan to value ratios. The BIS team found that institution-based prudential instruments (capital requirements or local currency reserve requirements) affected more the local lending of foreign affiliates, whereas activity-based instruments (loan-to-value ratios) primarily affected cross-border lending. Bank characteristics such as size, capitalization, and liquidity play a role in determining the magnitude of cross-border spillovers.

\section{Summary}

Macroprudential policies have been established as a key line of defense in preventing and mitigating the consequences of systemic financial crises. In recent years, the legal framework for macroprudential policy instruments has been defined, institutions have been further tasked with the surveillance and regulation of financial stability risks, and terms for applying macroprudential policy tools and for monitoring consequences have been specified. Given the urgency of addressing financial stability risks, policymakers moved forward with this toolbox before having comprehensive empirical and theoretical evidence on the expected effects, on possible spillovers, and on the effectiveness of macro-prudential policies.

This paper and the overall IBRN initiative provide evidence relevant for discussion of the international spillover effects of prudential policies used in a broad set of countries. The use of a common research methodology allows for comparability of results across countries and for drawing lessons from those country studies. Overall, the results of this prudential spillover work demonstrate the importance of incorporating considerations on the international spillovers of prudential instruments into discussions and frameworks around macroprudential policy, including the role and potential for reciprocity.

Key findings are, first, that prudential instruments spill over across borders through international bank lending. The sign of spillovers onto lending can be positive or negative, indicating that different constraints are binding for different types of banks and that banks substitute between different types of activities. Second, bank balance sheet conditions and business models in fact affect the intensity of spillovers. Evidence from some countries suggests that some global banks with strong balance sheets responded to tightening foreign regulations by expanding their market shares abroad as local banks presumably contract their balance sheets. Spillovers of foreign regulations into home lending are more likely to arise through hosted affiliates of foreign banks. Third, significant international spillovers of policy on loan 
growth have mostly not been large. One reason for this is that the analysis focuses on adjustment in loan growth along the intensive margin, excluding analysis of adjustment along the extensive margin through entry and exit into foreign markets and mergers and acquisitions. Moreover, countries have tested for prudential spillovers in the context of the relatively infrequent and newer use of some instruments. To the extent that domestic activation of macroprudential instruments increases, the scope for international spillovers of prudential instruments might thus increase in the future.

Overall, the results of this prudential spillover work demonstrate the importance of incorporating considerations on the international spillovers of prudential instruments into discussions and frameworks around macroprudential policy, including the role and potential for reciprocity. While spillovers do not always occur through lending, they do occur frequently enough to have consequences for countries interlinked through international banking.

\section{Bibliography}

Aiyar, S., C. Calomiris, and T. Wieladek. 2014. Does Macro-Prudential Regulation Leak? Evidence from a U.K. Policy Experiment. Journal of Money, Credit and Banking, 46 (1), February, 181-214.

Aiyar, S, C. Calomiris, J. Hooley, Y. Korniyenko, and T. Wieladek. 2014. The International Transmission of Bank Capital Requirements: Evidence from the United Kingdom. Journal of Financial Economics 113(3): 325-518.

Akinci, O. and J. Olmstead-Rumsey. 2015. How effective are macroprudential policies? An empirical investigation. International Finance Discussion Paper 1136, Board of Governors of the Federal Reserve System.

Arregui, N., J. Beneš, I. Krznar, S. Mitra, and A. Oliveira Santos. 2013. Evaluating the Net Benefits of Macroprudential Policy: A Cookbook. Working Paper 13/167. Washington DC.

Auer, S., M. Ganarin, and P. Towbin. 2016. International Banking and Cross-border effects of regulation: Lessons from Switzerland. Swiss National Bank manuscript.

Avdjiev, S., C. Koch, P. McGuire, and G. von Peter. 2016. International Prudential Policy Spillovers: A Global Perspective. BIS working papers no. 589 (October).

Bank for International Settlements. 2014. Debt and the financial cycle: domestic and global. 84th Annual Report, Chapter IV, June.

Barth, J. R., G. Caprio, and R. Levine. 2013. Bank Regulation and Supervision in 180 Countries from 1999 to 2011. Journal of Financial Economic Policy, Vol. 5(2), pp. 111-219, April.

Başkaya, Y. S., M. Binici, and T. Kenç. 2016. International Banking and Cross-Border Effects of Regulation: Lessons from Turkey. Central Bank of the Republic of Turkey manuscript.

Bengui, J. and J. Bianchi. 2014. Capital Flow Management when Capital Controls Leak. Manuscript.

Berrospide, J., R. Correa, L. Goldberg, and F. Niepmann. 2016. International Banking and Cross-border Effects of Regulation: Lessons from the United States. NBER Working Paper No. w22645. 
Bonfim, D. and S. Costa. 2016. International Banking and Cross-border effects of regulation: Lessons from Portugal. Central Bank of Portugal manuscript.

Borio, C. 2012. The financial cycle and macroeconomics. What have we learnt? BIS working papers no. 395 (December).

Bremus, F. and M. Fratzscher. 2015. Drivers of structural change in cross-border banking since the global financial crisis. Journal of International Money and Finance, 52, pp. 32-59.

Bruno, V. and H. S. Shin. 2014. Assessing Macroprudential Policies: Case of Korea. The Scandinavian Journal of Economics, 116(1), pp. 128-157.

Bruno, V., I. Shim and H. S. Shin. 2015. Effectiveness of Macroprudential and Capital Flow Measures in Asia and the Pacific. BIS paper no. 82.

Buch, C. M. and L. S. Goldberg. 2015. International Banking and Liquidity Risk Transmission: Lessons from Across Countries. IMF Economic Review vol. 63.

Bussière, M., J. Schmidt, and F. Vinas. 2016. International Banking and Cross-Border Effects of Regulation: Lessons from France. Banque de France No. 599.

Caccavaio, M., L. Carpinelli, and G. Marinelli. 2016. International Banking and Cross-border Effects of Regulation: Lessons from Italy. Banca d'Italia manuscript.

Cerutti, E., S. Claessens, and L. Laeven. 2015. The use and effectiveness of macroprudential policies: new evidence. Journal of Financial Stability.

Cerutti, E., R. Correa, E. Fiorentino, and E. Segalla. 2015. Changes in prudential policy instruments: a new cross country database. IMF working paper wp/16/110.

Claessens, S., M. A. Kose, and M. E. Terrones. 2011. Financial Cycles: What? How? When? IMF working paper. IMF working paper wp/11/76.

Claessens, S., S. R. Ghosh, and R. Mihet. 2014. Macro-Prudential Policies to Mitigate Financial System Vulnerabilities. IMF Working Paper wp/14/155.

Claessens, S. and N. van Horen. 2015. The Impact of the Global Financial Crisis on Banking Globalization. IMF ER. 63(4), pp. 868-918.

Damar, H. E. and A. Mordel. 2016. International Banking and Cross-Border Effects of Regulation: Lessons from Canada. Bank of Canada No. 16-34.

Drehmann, M., C. Borio, and K. Tsatsaronis. 2011. Anchoring countercyclical capital buffers: The role of credit aggregates. International Journal of Central Banking, 7(4).

Fischer, S. 2010. Central bank lessons from the global crisis. Lecture.

Frost, J., J. de Haan, and N. van Horen. 2016. International Banking and Cross-Border Effects of Regulation: Lessons from the Netherlands. De Nederlandsche Bank Working Paper No. 520.

Gajewski, K. and O. Krzesicki. 2016. International Banking and Cross-border effects of regulation: Lessons from Poland. Narodowy Bank Polski manuscript.

Henry, P. B. 2007. Capital Account Liberalization: Theory, Evidence, and Speculation. Journal of Economic Literature 45(4): 887-935.

Hills, R., D. Reinhardt, R. Sowerbutts, and T. Wieladek. 2016. Cross-Border Regulatory Spillovers: How Much? How Important? What Sectors? Lessons from the United Kingdom. Bank of England Working Paper No. 595. 
Ho, K., E. Wong, and E. Tan. 2016. International Banking and Cross-border effects of regulation: Lessons from Hong Kong. HKIMR Working Paper No. 12/2016.

Houston, J.F., C. Lin, and Y. Ma. 2012. Regulatory Arbitrage and International Bank Flows. Journal of Finance 67(5): 1845-1895.

International Monetary Fund (IMF). 2011. Macroprudential Policy: What Instruments and How to Use Them? Lessons from Country Experiences. IMF working paper wp/11/238.

Jara, A., L. Cabezas. 2016. International Banking and Cross-border effects of regulation: Lessons from Chile. Central Bank of Chile No 790.

Jiménez, G., S. Ongena, J.-L Peydro, and J. Saurina Salas. 2012. Macroprudential policy, countercyclical bank capital buffers and credit supply: Evidence from the Spanish dynamic provisioning experiments. National Bank of Belgium Working Paper No 231.

Kalemli-Ozcan, S., E. Papaioannou and J.-L Peydro. 2013. Financial Regulation, Financial Globalization and the Synchronization of Economic Activity, Journal of Finance, May, Vol. 68(3), 1179-1228.

Khwaja, A. I. and A. Mian. 2008. Tracing the Impact of Bank Liquidity Shocks: Evidence from an Emerging Market. American Economic Review 98(4), 1413-1442.

Kuttner, K. and I. Shim. 2013. Can non-interest rate policies stabilize housing markets? Evidence from a panel of 57 economies. NBER working paper w19723.

Leamer, E. E. 1988. Measures of openness, in R.E. Baldwin (ed.), Trade Policy Issues and Empirical Analysis, University of Chicago, Chicago and London, pp. 147-204.

Levin G., C. López, F. López-Gallo, and S. Martínez. 2016. International Banking and Cross-border effects of regulation: Lessons from Mexico. Banco de Mexico manuscript.

Melitz, Marc. 2003. The Impact of Trade on Intra-Industry Reallocations and Aggregate Industry Productivity. Econometrica 71: 1695-1725.

Nocciola, L. and D. Żochowski. 2016. International banking and cross-border effects of prudential regulation: Lessons from the euro area. European Central Bank working paper.

Obstfeld, M. 2014. Trilemmas and Tradeoffs: Living with Financial Globalization. Paper for Asian Monetary Policy Forum, Singapore.

Ohls, J., M. Pramor, and L. Tonzer. 2016. International Banking and Cross-Border Effects of Regulation: Lessons from Germany. Deutsche Bundesbank Discussion Paper 27/2016.

Ostry, J.D., A.R. Ghosh, K. Habermeier, L. Laeven, M. Chamon, M.S. Qureshi, and A. Kokenyne. 2011. Managing Capital Inflows: what tools to use? IMF Staff Discussion Note SDN/11/06.

Park, H. and J. Lee. 2016. International Banking and Cross-border effects of regulation: Lessons from Korea. Bank of Korea manuscript.

Reinhardt, D. and R. Sowerbutts. 2015. Regulatory arbitrage in action: evidence from banking flows and macroprudential policy. Bank of England Staff Working Paper No. 546.

Schindler, M. 2009. Measuring financial integration: a new data set. IMF Staff Papers, 56 (1): 222-238.

Vandenbussche, J., U. Vogel, and E. Detragiache. 2015. Macroprudential Policies and Housing Prices-A New Database and Empirical Evidence for Central, Eastern, and Southeastern Europe. Journal of Money, Credit, and Banking. 47(S1) pp. 343-377. 


\section{Figure 1: Transmission Channels of Regulatory Policies}

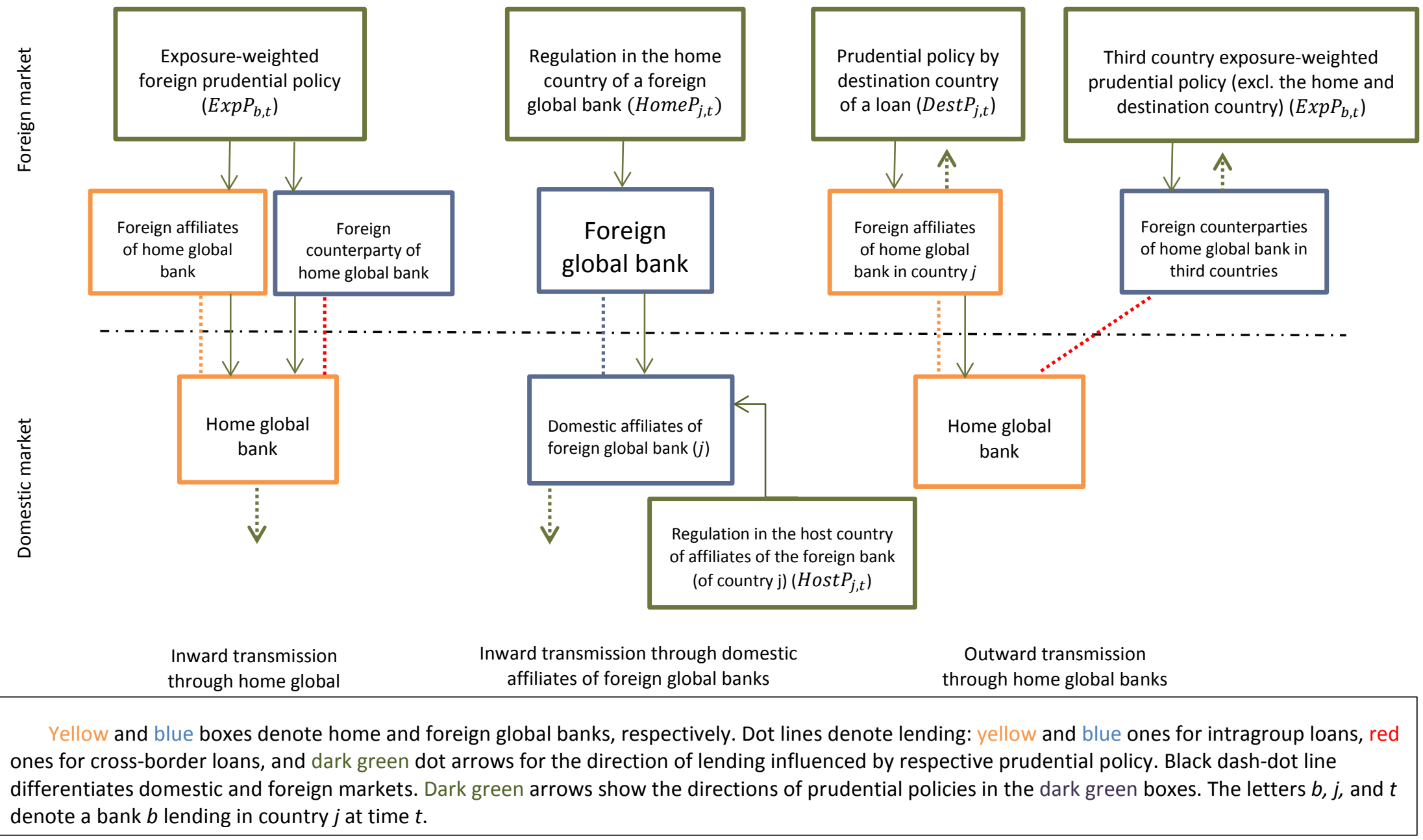




\section{Table 1: Variation of Prudential Instruments}

This Table summarizes the changes in prudential instruments, based on the database which is described in more detail in Cerutti et al. (2015). The table gives the number of countries which changed regulations within the sample period (2000-2014) and the number of such quarterly changes, broken down into policy tightening and loosening. The entries distinguish the total from a restricted sample, including the United States, the United Kingdom, Japan, Germany, France and Switzerland.

List of countries in the Prudential Instruments Database [64]: Argentina, Australia, Austria, Belgium, Brazil, Bulgaria, Canada, Chile, China, Colombia, Croatia, Czech Republic, Denmark, Estonia, Finland, France, Germany, Greece, Hong Kong, Hungary, Iceland, India, Indonesia, Ireland, Israel, Italy, Japan, Kuwait, Latvia, Lebanon, Lithuania, Luxembourg, Malaysia, Malta, Mexico, Mongolia, Netherlands, New Zealand, Nigeria, Norway, Peru, Philippines, Poland, Portugal, Romania, Russia, Saudi Arabia, Serbia, Singapore, Slovakia, Slovenia, South Africa, South Korea, Spain, Sweden, Switzerland, Taiwan, Thailand, Turkey, Ukraine, United Kingdom, United States, Uruguay, Vietnam

\begin{tabular}{|c|c|c|c|c|c|c|c|c|}
\hline \multirow[b]{2}{*}{ Prudential instrument } & \multicolumn{4}{|c|}{ Full sample } & \multicolumn{4}{|c|}{ Restricted sample } \\
\hline & $\begin{array}{c}\# \\
\text { countries }\end{array}$ & $\begin{array}{c}\# \\
\text { changes }\end{array}$ & $\begin{array}{c}\# \\
\text { tightening }\end{array}$ & $\begin{array}{c}\# \\
\text { loosening }\end{array}$ & $\begin{array}{c}\# \\
\text { countries }\end{array}$ & $\begin{array}{c}\# \\
\text { changes }\end{array}$ & $\begin{array}{c}\# \\
\text { tightening }\end{array}$ & $\begin{array}{c}\# \\
\text { loosening }\end{array}$ \\
\hline $\begin{array}{l}\text { General capital } \\
\text { requirements }\end{array}$ & 55 & 100 & 100 & 0 & 6 & 12 & 12 & 0 \\
\hline $\begin{array}{l}\text { Sector specific capital } \\
\text { buffer }\end{array}$ & 29 & 73 & 54 & 19 & 1 & 3 & 3 & 0 \\
\hline $\begin{array}{l}\text { Loan-to-value ratio } \\
\text { limits }\end{array}$ & 36 & 97 & 72 & 25 & 0 & 0 & 0 & 0 \\
\hline $\begin{array}{l}\text { Reserve } \\
\text { requirements: } \\
\text { Foreign }\end{array}$ & 21 & 141 & 90 & 51 & 0 & 0 & 0 & 0 \\
\hline $\begin{array}{l}\text { Reserve } \\
\text { requirements: Local }\end{array}$ & 46 & 297 & 131 & 166 & 2 & 4 & 0 & 4 \\
\hline $\begin{array}{l}\text { Interbank exposure } \\
\text { limit }\end{array}$ & 14 & 25 & 24 & 1 & 3 & 8 & 8 & 0 \\
\hline Concentration ratio & 22 & 34 & 32 & 2 & 1 & 4 & 4 & 0 \\
\hline
\end{tabular}




\section{Table 2: Types of Specification by Country}

This Table summarizes the transmission channels studied by particular country teams, along with the total number of regressions by country (row) and channel (column). The specifications differ in transmission channel (Exposureweighted inward transmission, Inward transmission of home policy via affiliates, Outward transmission) and in the inclusion of bank variable interactions and business and financial cycles. ${ }^{*}$ The Outward transmission channel looks primarily at effects on lending from destination country policy. Third-country exposure-weighted effects are included in addition to destination country policy in one exercise.

\begin{tabular}{|c|c|c|c|c|}
\hline & \multicolumn{2}{|c|}{ Inward transmission of... } & \multirow{2}{*}{$\begin{array}{c}\text { Outward } \\
\text { transmission of... } \\
\begin{array}{c}\text { Destination country } \\
\text { policy* }\end{array}\end{array}$} & \multirow[b]{2}{*}{ Tota } \\
\hline & $\begin{array}{l}\text { Exposure- } \\
\text { weighted } \\
\text { regulation }\end{array}$ & $\begin{array}{l}\text { Home prudential } \\
\text { policy via affiliates }\end{array}$ & & \\
\hline Canada & & & $\checkmark$ & 33 \\
\hline Chile & $\checkmark$ & $\checkmark$ & & 53 \\
\hline France & & & $\checkmark$ & 35 \\
\hline Germany & $\checkmark$ & $\checkmark$ & $\checkmark$ & 84 \\
\hline Hong Kong & & $\checkmark$ & & 25 \\
\hline Italy & & & $\checkmark$ & 32 \\
\hline Mexico & $\checkmark$ & $\checkmark$ & & 52 \\
\hline Netherlands & & & $\checkmark$ & 35 \\
\hline Poland & & $\checkmark$ & & 28 \\
\hline Portugal & $\checkmark$ & $\checkmark$ & & 49 \\
\hline South Korea & & $\checkmark$ & & 35 \\
\hline Switzerland & $\checkmark$ & & & 24 \\
\hline Turkey & $\checkmark$ & $\checkmark$ & & 48 \\
\hline United Kingdom & $\checkmark$ & $\checkmark$ & & 56 \\
\hline United States & $\checkmark$ & $\checkmark$ & $\checkmark$ & 86 \\
\hline Total & 199 & 281 & 195 & 675 \\
\hline
\end{tabular}




\section{Table 3: Counts of Countries and Models Included in the Meta-Analysis}

This Table summarizes the number of countries and regression specifications for each combination of prudential instrument (rows) and channel (columns), preceded by the number of regressions reported in total across all channels. The specifications differ in transmission channel (Exposure-weighted inward transmission, Inward transmission of home policy via affiliates, Outward transmission) and in the inclusion of bank variable interactions and business and financial cycles. Countries included are Canada, Chile, France, Germany, Hong Kong, Italy, South Korea, Mexico, Netherlands, Poland, Portugal, Switzerland, Turkey, the United Kingdom, and the United States. *The Outward transmission channel looks primarily at effects on lending from destination country policy. Thirdcountry exposure-weighted effects are included in addition to destination country policy in one exercise.

\begin{tabular}{|c|c|c|c|c|c|c|c|c|}
\hline & \multicolumn{2}{|c|}{ Total number } & \multicolumn{4}{|c|}{ Inward transmission of... } & \multicolumn{2}{|c|}{$\begin{array}{c}\text { Outward } \\
\text { transmission of...... } \\
\text { Destination country } \\
\text { policy* }\end{array}$} \\
\hline & $\begin{array}{c}\# \\
\text { Countries } \\
\end{array}$ & $\begin{array}{c}\# \\
\text { Models } \\
\end{array}$ & $\begin{array}{c}\# \\
\text { Countries } \\
\end{array}$ & $\begin{array}{c}\# \\
\text { Models }\end{array}$ & $\begin{array}{c}\# \\
\text { Countries }\end{array}$ & $\begin{array}{c}\# \\
\text { Models }\end{array}$ & $\begin{array}{c}\# \\
\text { Countries }\end{array}$ & $\begin{array}{c}\# \\
\text { Models }\end{array}$ \\
\hline $\begin{array}{l}\text { General capital } \\
\text { requirements }\end{array}$ & 15 & 113 & 8 & 32 & 10 & 51 & 6 & 30 \\
\hline $\begin{array}{l}\text { Sector specific capital } \\
\text { buffer }\end{array}$ & 15 & 110 & 8 & 32 & 10 & 48 & 6 & 30 \\
\hline $\begin{array}{l}\text { Loan-to-value ratio } \\
\text { limits }\end{array}$ & 15 & 110 & 8 & 32 & 10 & 49 & 6 & 29 \\
\hline $\begin{array}{l}\text { Reserve } \\
\text { requirements: } \\
\text { Foreign }\end{array}$ & 12 & 76 & 7 & 27 & 4 & 19 & 6 & 30 \\
\hline $\begin{array}{l}\text { Reserve } \\
\text { requirements: Local }\end{array}$ & 14 & 106 & 7 & 28 & 10 & 48 & 6 & 30 \\
\hline $\begin{array}{l}\text { Interbank exposure } \\
\text { limit }\end{array}$ & 12 & 68 & 5 & 20 & 6 & 25 & 5 & 23 \\
\hline Concentration ratio & 14 & 92 & 7 & 28 & 9 & 41 & 5 & 23 \\
\hline
\end{tabular}




\section{Table 4: Effects of Prudential Instruments on Lending Growth}

This Table details - by instrument, channel, and sign - the percentage of prudential instrument net effects significant at the $10 \%$ level. Net effects are calculated as the sum of all instrument coefficients in a given regression, multiplying interaction coefficients by the mean of their interacted control. $0=$ insignificant, $+=$ positive, - = negative. An F-test is used to test whether this linear combination of coefficients is nonzero. *For the Outward transmission exercise in which both Destination country and third-country exposure-weighted policy instruments were considered simultaneously; if either of these two current-lagged coefficient sums were statistically significant, the net effect for this regression is considered significant.

\begin{tabular}{|c|c|c|c|c|c|c|c|c|c|}
\hline & \multicolumn{6}{|c|}{ Inward transmission of... } & \multirow{2}{*}{\multicolumn{3}{|c|}{$\begin{array}{c}\text { Outward transmission } \\
\text { of...... } \\
\text { Destination country } \\
\text { policy* }\end{array}$}} \\
\hline & \multicolumn{3}{|c|}{$\begin{array}{c}\text { Exposure-weighted } \\
\text { regulation }\end{array}$} & \multicolumn{3}{|c|}{ Home policy via affiliates } & & & \\
\hline & (a) & (b) & (c) & (a) & (b) & (c) & (a) & (b) & (c) \\
\hline & 0 & + & - & 0 & + & - & 0 & + & - \\
\hline $\begin{array}{l}\text { General capital } \\
\text { requirements }\end{array}$ & 75 & 19 & 6 & 92 & 0 & 8 & 70 & 23 & 7 \\
\hline Sector specific capital buffer & 94 & 6 & 0 & 73 & 15 & 13 & 77 & 20 & 3 \\
\hline Loan-to-value ratio limits & 72 & 19 & 9 & 69 & 18 & 12 & 93 & 7 & 0 \\
\hline $\begin{array}{l}\text { Reserve requirements: } \\
\text { Foreign }\end{array}$ & 74 & 15 & 11 & 74 & 11 & 16 & 67 & 27 & 7 \\
\hline Reserve requirements: Local & 89 & 4 & 7 & 75 & 19 & 6 & 33 & 47 & 20 \\
\hline Interbank exposure limit & 80 & 5 & 15 & 76 & 8 & 16 & 70 & 4 & 26 \\
\hline Concentration ratio & 79 & 11 & 11 & 66 & 22 & 12 & 87 & 9 & 4 \\
\hline
\end{tabular}




\section{Table 5: Country Breakdown of Prudential Instrument Significance by Instrument and Channel}

This Table reports the country teams which found a $10 \%$ significant net effect on lending by instrument, channel, and sign, adding a country dimension to the results of Table 4. Also reported are countries which ran exercises for a given instrument and channel, but which found no significant net effects. $0=$ insignificant, $+=$ positive, $-=$ negative. Note that it is possible for a country to find both positive and negative net effects across exercises within a channel, and to therefore appear in both columns $b$ and c. Countries included are Canada (CA), Chile (CL), France (FR), Germany (DE), Hong Kong (HK), Italy (IT), South Korea (KR), Mexico (MX), Netherlands (NL), Poland (PL), Portugal (PT), Switzerland (CH), Turkey (TR), the United Kingdom (UK), and the United States (US). *For the Outward transmission exercise in which both Destination country and third-country exposure-weighted policy instruments were considered simultaneously; if either of these two current-lagged coefficient sums were statistically significant, the net effect for this regression is considered significant.

\begin{tabular}{|c|c|c|c|c|c|c|c|c|c|}
\hline \multirow{4}{*}{$\begin{array}{l}\text { Prudential } \\
\text { Instrument }\end{array}$} & \multicolumn{6}{|c|}{ Inward transmission of... } & \multirow{2}{*}{\multicolumn{3}{|c|}{$\begin{array}{l}\text { Outward transmission of... } \\
\text { Destination country policy* }\end{array}$}} \\
\hline & \multicolumn{3}{|c|}{$\begin{array}{l}\text { Exposure-weighted } \\
\text { regulation }\end{array}$} & \multicolumn{3}{|c|}{ Home policy via affiliates } & & & \\
\hline & (a) & (b) & (c) & (a) & (b) & (c) & (a) & (b) & (c) \\
\hline & 0 & + & - & 0 & + & - & 0 & + & - \\
\hline $\begin{array}{l}\text { General capital } \\
\text { requirements }\end{array}$ & $\begin{array}{l}\mathrm{MX}, \mathrm{PT} \\
\mathrm{TR}\end{array}$ & $\begin{array}{l}\text { CL,DE, } \\
\text { US }\end{array}$ & $\mathrm{CH}, \mathrm{UK}$ & $\begin{array}{c}C L, D E \\
K R, M X, \\
T R, U K, \\
\text { US }\end{array}$ & & $\begin{array}{l}\text { HK,PL, } \\
\text { PT }\end{array}$ & FR,IT & $\begin{array}{l}\text { CA,NL, } \\
\text { US }\end{array}$ & DE,US \\
\hline $\begin{array}{l}\text { Sector specific } \\
\text { capital buffer }\end{array}$ & $\begin{array}{l}\mathrm{CH}, \mathrm{CL} \\
\mathrm{DE}, \mathrm{TR} \\
\text { UK,US }\end{array}$ & $\mathrm{MX}, \mathrm{PT}$ & & $\begin{array}{c}\mathrm{MX}, \mathrm{PL}, \\
\mathrm{UK}\end{array}$ & $\begin{array}{l}\text { CL,PT, } \\
\text { TR,US }\end{array}$ & $\begin{array}{l}\mathrm{DE}, \mathrm{HK} \\
\mathrm{KR}, \mathrm{TR}\end{array}$ & DE & $\begin{array}{l}\text { CA,FR, } \\
\text { IT,NL }\end{array}$ & US \\
\hline $\begin{array}{l}\text { Loan-to-value ratio } \\
\text { limits }\end{array}$ & $\begin{array}{l}\text { CL,UK, } \\
\text { US }\end{array}$ & $\begin{array}{l}\mathrm{CH}, \mathrm{DE}, \\
\mathrm{TR}\end{array}$ & $\mathrm{MX}, \mathrm{PT}$ & $\begin{array}{l}\mathrm{CL}, \mathrm{KR} \\
\mathrm{MX}, \mathrm{PL}\end{array}$ & $\begin{array}{l}\text { PT,TR, } \\
\text { UK,US }\end{array}$ & $\begin{array}{l}\text { DE,HK, } \\
\text { TR }\end{array}$ & $\begin{array}{l}\text { CA,DE, } \\
\text { FR,US }\end{array}$ & $\mathrm{IT}, \mathrm{NL}$ & \\
\hline $\begin{array}{l}\text { Reserve } \\
\text { requirements: } \\
\text { Foreign }\end{array}$ & $\mathrm{CH}, \mathrm{US}$ & $\begin{array}{l}\text { CL,PT, } \\
\text { UK }\end{array}$ & $\mathrm{DE}, \mathrm{MX}$ & UK & $C L, D E$ & $\mathrm{KR}$ & $\mathrm{DE}$ & $\begin{array}{l}\text { CA,FR, } \\
\text { IT,NL }\end{array}$ & NL,US \\
\hline $\begin{array}{l}\text { Reserve } \\
\text { requirements: Local }\end{array}$ & $\begin{array}{l}C L, D E \\
M X, U S\end{array}$ & UK & PT, TR & $\mathrm{CL}, \mathrm{UK}$ & $\begin{array}{l}\text { DE,HK, } \\
\text { PL,PT, } \\
\text { TR,US }\end{array}$ & $\begin{array}{l}\mathrm{HK}, \mathrm{KR}, \\
\mathrm{MX}\end{array}$ & & $\begin{array}{l}\text { CA,FR, } \\
\text { IT,NL }\end{array}$ & DE,US \\
\hline $\begin{array}{l}\text { Interbank exposure } \\
\text { limit }\end{array}$ & UK & $\mathrm{TR}$ & $\begin{array}{l}\mathrm{CH}, \mathrm{MX} \\
\text { US }\end{array}$ & $\begin{array}{c}\mathrm{HK}, \\
\mathrm{PL}, \mathrm{UK}\end{array}$ & $\mathrm{MX}, \mathrm{TR}$ & $\mathrm{KR}, \mathrm{TR}$ & $\begin{array}{l}\text { CA,IT, } \\
\text { US }\end{array}$ & NL & $\mathrm{FR}, \mathrm{NL}$ \\
\hline Concentration ratio & $\begin{array}{l}\mathrm{CH}, \mathrm{CL} \\
\mathrm{DE}\end{array}$ & $\begin{array}{l}\text { MX,PT, } \\
\text { TR }\end{array}$ & MX,UK & $\mathrm{HK}, \mathrm{PL}$ & $\begin{array}{l}\text { CL,DE, } \\
\text { PT,TR }\end{array}$ & $\begin{array}{l}\mathrm{KR}, \mathrm{MX} \\
\mathrm{UK}\end{array}$ & $C A, D E$ & $\mathrm{FR}, \mathrm{IT}$ & NL \\
\hline
\end{tabular}




\section{Table 6: Heterogeneity of Effects across Banks by Instrument, Channel, and Balance Sheet Characteristic}

This Table shows the countries which found particular balance sheet characteristics to be important in differentiating the impacts of prudential regulations on bank lending growth, defined as having found instrument-bank interaction sums $\left(\beta_{1}+\beta_{2}+\beta_{3}\right)$ to be significant at the $10 \%$ level using an F-test. Countries included are Canada (CA), Chile (CL), France (FR), Germany (DE), Hong Kong (HK), Italy (IT), South Korea (KR), Mexico (MX), Netherlands (NL), Poland (PL), Portugal (PT), Switzerland (CH), Turkey (TR), the United Kingdom (UK), and the United States (US). All countries running a bank interaction regression in a given channel are listed in the final row, with the following exceptions: †Due to data availability, $\mathrm{CH}, \mathrm{IT}, \mathrm{MX}, \mathrm{NL}, \mathrm{TR}$, and the UK do not include net due variables, while NL also does not include an illiquid asset ratio. $\neq$ Due to insufficient variation, foreign reserve requirements are excluded by TR, local reserve requirements by $\mathrm{CH}$, concentration ratios by US, and interbank exposure limits by $\mathrm{CL}$, DE, and PT in all channels. In the via affiliates channel, foreign reserve requirements are similarly excluded by HK, MX, PL, PT, TR, and US, with interbank exposure limits also excluded by US in this channel.

\begin{tabular}{|c|c|c|c|c|c|c|c|c|c|c|c|c|c|c|c|}
\hline \multicolumn{16}{|c|}{ Countries with Significant Heterogeneity by Bank Characteristic } \\
\hline & \multicolumn{10}{|c|}{ Inward transmission of... } & \multirow{2}{*}{\multicolumn{5}{|c|}{$\begin{array}{l}\text { Outward transmission of... } \\
\text { Destination country policy* }\end{array}$}} \\
\hline & \multicolumn{5}{|c|}{ Exposure-weighted regulation } & \multicolumn{5}{|c|}{ Home policy via affiliates } & & & & & \\
\hline & $\begin{array}{c}\text { Total } \\
\text { assets } \\
\end{array}$ & Tier 1 & $\begin{array}{l}\text { Illiquid } \\
\text { assets† }\end{array}$ & $\begin{array}{c}\text { Net } \\
\text { due }\end{array}$ & $\begin{array}{c}\text { Core } \\
\text { deposits } \\
\end{array}$ & $\begin{array}{c}\text { Total } \\
\text { assets } \\
\end{array}$ & Tier 1 & $\begin{array}{l}\text { Illiquid } \\
\text { assetst }\end{array}$ & $\begin{array}{c}\text { Net } \\
\text { due }\end{array}$ & $\begin{array}{c}\text { Core } \\
\text { deposits } \\
\end{array}$ & $\begin{array}{c}\text { Total } \\
\text { assets } \\
\end{array}$ & Tier 1 & $\begin{array}{l}\text { Illiquid } \\
\text { assets† }\end{array}$ & $\begin{array}{c}\text { Net } \\
\text { duet }\end{array}$ & $\begin{array}{c}\text { Core } \\
\text { deposits }\end{array}$ \\
\hline $\begin{array}{l}\text { General capital } \\
\text { requirements }\end{array}$ & $\begin{array}{l}\text { CL,PT, } \\
\text { TR }\end{array}$ & $\mathrm{CL}, \mathrm{PT}$ & $\mathrm{CH}, \mathrm{TR}$ & PT & $\begin{array}{l}\mathrm{CH}, \mathrm{PT}, \\
\mathrm{UK}, \mathrm{US}\end{array}$ & $\mathrm{HK}, \mathrm{KR}$ & $\begin{array}{l}\text { CL,HK, } \\
\text { US }\end{array}$ & $\mathrm{CL}, \mathrm{PL}$ & $\begin{array}{l}\mathrm{DE}, \mathrm{PL}, \\
\mathrm{PT}, \mathrm{US}\end{array}$ & $\mathrm{CL}$ & $\mathrm{DE}, \mathrm{FR}$ & $\mathrm{DE}, \mathrm{US}$ & FR & & \\
\hline $\begin{array}{l}\text { Sector specific capital } \\
\text { buffer }\end{array}$ & & UK & PT,US & & PT & TR & $\begin{array}{l}\mathrm{HK}, \\
\mathrm{KR}, \mathrm{US}\end{array}$ & $\begin{array}{c}\text { DE, } \\
K R, P T, \\
\text { UK,US }\end{array}$ & $\mathrm{KR}$ & $\begin{array}{l}\mathrm{DE}, \mathrm{KR}, \\
\mathrm{UK}\end{array}$ & $\mathrm{DE}, \mathrm{IT}$ & $\mathrm{NL}$ & & CA & $\mathrm{CA}, \mathrm{NL}$ \\
\hline $\begin{array}{l}\text { Loan-to-value ratio } \\
\text { limits }\end{array}$ & $\begin{array}{l}\mathrm{CH}, \mathrm{CL}, \\
\mathrm{PT}\end{array}$ & $\mathrm{CL}, \mathrm{MX}$ & & PT & $\mathrm{CL}, \mathrm{PT}$ & $\begin{array}{l}\text { HK,KR, } \\
\text { TR,US }\end{array}$ & $\begin{array}{l}\text { HK, } \\
\text { PT,UK }\end{array}$ & $\begin{array}{l}\mathrm{CL}, \mathrm{HK}, \\
\mathrm{MX}, \mathrm{PL}, \\
\mathrm{PT}, \mathrm{UK}\end{array}$ & $\mathrm{DE}, \mathrm{PT}$ & $\begin{array}{c}\text { DE,HK, } \\
\text { KR,MX, } \\
\text { PT,TR }\end{array}$ & CA & $\mathrm{NL}$ & CA & $\mathrm{DE}$ & $\mathrm{NL}$ \\
\hline $\begin{array}{l}\text { Reserve requirements: } \\
\text { Foreign } \ddagger\end{array}$ & $\mathrm{MX}, \mathrm{PT}$ & $\begin{array}{l}\mathrm{CH}, \mathrm{DE}, \\
\mathrm{MX}, \mathrm{PT}\end{array}$ & PT,UK & $\begin{array}{l}\mathrm{CL,DE}, \\
\text { PT }\end{array}$ & US & KR UK & UK & & & $\mathrm{KR}, \mathrm{UK}$ & NL,US & $\begin{array}{l}\mathrm{CA}, \mathrm{NL}, \\
\text { US }\end{array}$ & $\mathrm{DE}$ & & $\mathrm{DE}, \mathrm{US}$ \\
\hline $\begin{array}{l}\text { Reserve requirements: } \\
\text { Local }\end{array}$ & $\mathrm{TR}$ & $\mathrm{TR}$ & $\mathrm{DE}, \mathrm{TR}$ & $\mathrm{CL}$ & US & $\begin{array}{l}\mathrm{DE} \\
\mathrm{KR}, \mathrm{TR}\end{array}$ & $\mathrm{DE}, \mathrm{KR}$ & $\begin{array}{l}\mathrm{DE}, \mathrm{HK} \\
\mathrm{PL}\end{array}$ & HK,US & $\begin{array}{l}\mathrm{HK}, \mathrm{KR}, \\
\mathrm{TR}\end{array}$ & US & $\mathrm{CA}, \mathrm{NL}$ & $C A, D E$ & $\mathrm{DE}$ & \\
\hline $\begin{array}{l}\text { Interbank exposure } \\
\text { limit } \ddagger\end{array}$ & & TR & TR,US & US & TR,UK & $\mathrm{KR}, \mathrm{TR}$ & $\mathrm{KR}$ & $\begin{array}{l}\mathrm{KR}, \\
\mathrm{PL}, \mathrm{TR}\end{array}$ & $\mathrm{HK}, \mathrm{KR}$ & $\mathrm{KR}, \mathrm{TR}$ & $\mathrm{CA}, \mathrm{NL}$ & & $\mathrm{FR}$ & $\begin{array}{l}\mathrm{CA} \\
\mathrm{FR}\end{array}$ & \\
\hline Concentration ratio $\ddagger$ & $\mathrm{CL}, \mathrm{MX}$ & $\begin{array}{l}\text { DE,MX } \\
\text { PT,TR }\end{array}$ & $\mathrm{PT}, \mathrm{TR}$ & DE & $\begin{array}{c}\text { CL,MX, } \\
\text { PT }\end{array}$ & $\begin{array}{c}\mathrm{HK}, \mathrm{MX} \\
\mathrm{TR}\end{array}$ & $\mathrm{MX}, \mathrm{TR}$ & $\begin{array}{l}\text { MX,PT, } \\
\text { TR }\end{array}$ & PL,PT & $\begin{array}{c}\mathrm{DE}, \mathrm{MX} \\
\mathrm{PT}\end{array}$ & $\mathrm{IT}, \mathrm{NL}$ & NL & $\mathrm{CA}$ & & CA,IT \\
\hline Countries reporting & \multicolumn{5}{|c|}{$\mathrm{CH}, \mathrm{CL}, \mathrm{DE}, \mathrm{MX}, \mathrm{PT}, \mathrm{TR}, \mathrm{UK}, \mathrm{US}$} & \multicolumn{5}{|c|}{$\mathrm{CL}, \mathrm{DE}, \mathrm{HK}, \mathrm{KR}, \mathrm{MX}, \mathrm{PL}, \mathrm{PT}, \mathrm{TR}, \mathrm{UK}, \mathrm{US}$} & \multicolumn{5}{|c|}{$C A, D E, F R, I T, N L$, US } \\
\hline
\end{tabular}




\section{Table 7: Probit Regression Analysis of Significance by Prudential Instrument}

This Table shows the features of regressions yielding significant impacts of prudential regulations on bank lending. The cells of the Table present Probit regression coefficients,

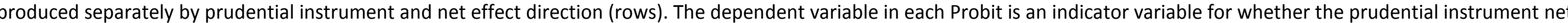
effect associated with a regression was significant at the $10 \%$ level. In the latter two rows for each instrument, this net effect is further required to be positively or negatively

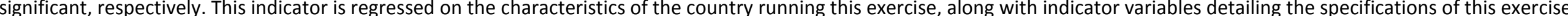

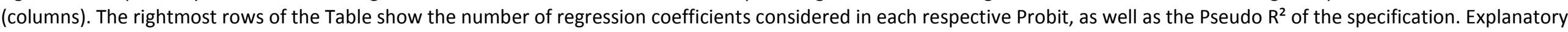
variables are defined in the Appendix. Standard errors are clustered by country. ${ }^{* *},{ }^{* *}$, and ${ }^{*}$ indicate significance at the $1 \%, 5 \%$, and $10 \%$ level, respectively. + Due to unstable coefficient estimates in the full model, \% foreign bank ownership was dropped as a control in the analysis of positively significant interbank exposure limit effects.

\begin{tabular}{|c|c|c|c|c|c|c|c|c|c|c|c|}
\hline & $\begin{array}{l}\text { Direction of } \\
\text { Significance }\end{array}$ & $\begin{array}{c}\text { Emerging } \\
\text { Market }\end{array}$ & $\begin{array}{l}\text { Inward } \\
\text { Exposure- } \\
\text { Weighted }\end{array}$ & $\begin{array}{c}\text { Outward } \\
\text { Transmission }\end{array}$ & $\begin{array}{l}\mathrm{PP} * \text { Cycle } \\
\text { Indicator }\end{array}$ & $\begin{array}{l}\mathrm{PP} * \text { Bank } \\
\text { Indicator }\end{array}$ & $\begin{array}{c}\text { All PP } \\
\text { Indicator }\end{array}$ & $\begin{array}{c}\% \\
\text { Tightening } \\
\end{array}$ & $\begin{array}{c}\text { \% Foreign } \\
\text { Bank } \\
\text { Ownership } \\
\end{array}$ & Observations & $\mathrm{R}^{2}$ \\
\hline \multirow{3}{*}{$\begin{array}{l}\text { General capital } \\
\text { requirements }\end{array}$} & (all) & -0.64 & $1.25^{* *}$ & $2.24 * * *$ & 0.23 & -0.18 & -0.20 & $0.02 * *$ & $0.03 * * *$ & 113 & 0.22 \\
\hline & (positive) & -0.04 & $7.84 * * *$ & $9.65^{* * *}$ & 0.05 & -0.32 & 0.29 & 0.02 & 0.02 & 113 & 0.36 \\
\hline & (negative) & $-0.92 * * *$ & 0.26 & 0.16 & 0.23 & -0.07 & $-4.89 * * *$ & 0.01 & $0.03^{* * *}$ & 113 & 0.21 \\
\hline \multirow{3}{*}{$\begin{array}{l}\text { Sector specific } \\
\text { capital buffer }\end{array}$} & (all) & $-0.49 * *$ & $-0.95 * *$ & 0.12 & -0.62 & -0.06 & $-0.92 * *$ & $0.03 * *$ & $-0.01 * *$ & 110 & 0.16 \\
\hline & (positive) & -0.25 & -0.48 & 0.52 & -0.58 & -0.11 & $-0.96 * *$ & 0.02 & -0.01 & 110 & 0.11 \\
\hline & (negative) & -0.86 & $-5.05^{* * *}$ & -0.51 & -0.29 & 0.07 & -0.36 & 0.03 & -0.01 & 110 & 0.21 \\
\hline \multirow{3}{*}{$\begin{array}{l}\text { Loan-to-value } \\
\text { ratio limits }\end{array}$} & (all) & -0.17 & -0.21 & -0.99 & -0.09 & 0.43 & 0.43 & -0.00 & -0.02 & 110 & 0.12 \\
\hline & (positive) & -0.17 & -0.03 & -0.54 & 0.29 & 0.23 & 0.48 & -0.01 & -0.01 & 110 & 0.08 \\
\hline & (negative) & 0.03 & -0.13 & $-5.20 * * *$ & $-4.88 * * *$ & 0.61 & 0.16 & $0.06 * *$ & -0.02 & 110 & 0.31 \\
\hline \multirow{3}{*}{$\begin{array}{l}\text { Reserve } \\
\text { requirements: } \\
\text { Foreign }\end{array}$} & (all) & -0.19 & 0.49 & $1.03^{*}$ & -0.42 & -0.44 & -0.47 & $0.02 * *$ & -0.01 & 76 & 0.08 \\
\hline & (positive) & 0.10 & 0.22 & $0.92 * * *$ & -0.20 & -0.31 & $-1.05 * *$ & -0.01 & -0.01 & 76 & 0.10 \\
\hline & (negative) & -5.34 & 12.40 & 12.37 & -0.67 & -0.67 & 0.45 & 0.38 & -0.01 & 76 & 0.38 \\
\hline \multirow{3}{*}{$\begin{array}{l}\text { Reserve } \\
\text { requirements: } \\
\text { Local }\end{array}$} & (all) & -0.06 & -0.45 & $1.20 * * *$ & -0.33 & -0.60 & -0.32 & -0.00 & $0.01^{*}$ & 106 & 0.21 \\
\hline & (positive) & -0.71 & $-0.90^{*}$ & $1.51 * *$ & -0.45 & $-1.04 * *$ & -0.20 & -0.01 & $0.02 *$ & 106 & 0.25 \\
\hline & (negative) & 0.59 & 0.16 & -0.64 & 0.18 & 0.18 & $-0.60 *$ & 0.01 & -0.00 & 106 & 0.17 \\
\hline \multirow{3}{*}{$\begin{array}{l}\text { Interbank } \\
\text { exposure limit }\end{array}$} & (all) & $1.87 * *$ & -0.43 & 1.15 & $-1.14 * *$ & 0.13 & 0.69 & $-0.05^{* * *}$ & $-0.07 * *$ & 68 & 0.36 \\
\hline & (positive) ${ }^{\dagger}$ & 17.42 & -11.78 & 81.82 & -4.91 & -6.03 & $52.92 * * *$ & $1.17^{* * *}$ & & 68 & 0.91 \\
\hline & (negative) & $1.28 *$ & -0.20 & 0.27 & -0.89 & 0.18 & -0.31 & $-0.05 * * *$ & $-0.06 * *$ & 68 & 0.24 \\
\hline \multirow{3}{*}{$\begin{array}{l}\text { Concentration } \\
\text { ratio }\end{array}$} & (all) & 0.08 & -0.50 & -0.35 & 0.28 & 0.06 & $0.88^{* * *}$ & -0.00 & -0.00 & 92 & 0.10 \\
\hline & (positive) & $0.76^{*}$ & -0.62 & 0.51 & $0.97^{*}$ & 0.54 & 0.62 & -0.00 & $-0.03 * *$ & 92 & 0.25 \\
\hline & (negative) & -0.44 & -0.04 & $-2.94 *$ & $-5.25 * * *$ & $-0.67 * * *$ & $0.95^{* *}$ & $-0.05^{*}$ & 0.02 & 92 & 0.37 \\
\hline
\end{tabular}




\section{Appendix Table A1: Heterogeneity of Effects across Cycles by Instrument and Channel}

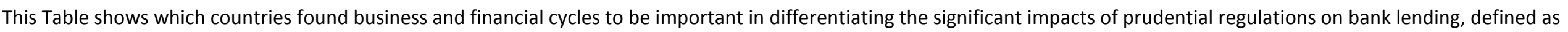

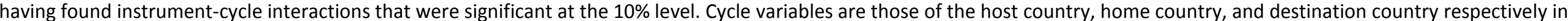

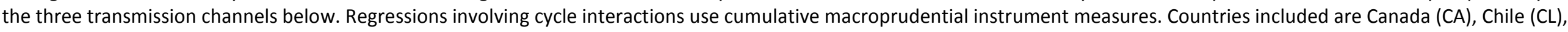

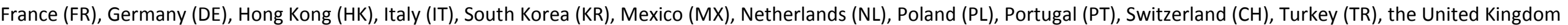
(UK), and the United States (US). All countries running a bank interaction regression in a given channel are listed in the final row. $¥ D u e$ to insufficient variation, foreign reserve

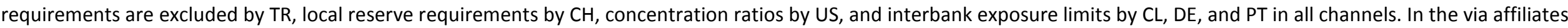
channel, foreign reserve requirements are similarly excluded by HK, MX, PL, PT, TR, and US, with interbank exposure limits also excluded by US in this channel.

\begin{tabular}{|c|c|c|c|c|c|c|c|c|c|c|c|c|}
\hline \multicolumn{13}{|c|}{ Countries with Significant Heterogeneity by Business and Financial Cycle } \\
\hline \multirow{4}{*}{$\begin{array}{r}\text { Channel: } \\
\text { Interaction: } \\
\text { Sign of Interaction: } \\
\end{array}$} & \multicolumn{8}{|c|}{ Inward transmission of... } & \multirow{2}{*}{\multicolumn{4}{|c|}{$\begin{array}{l}\text { Outward transmission of... } \\
\text { Destination country policy* }\end{array}$}} \\
\hline & \multicolumn{4}{|c|}{ Exposure-weighted regulation } & \multicolumn{4}{|c|}{ Home policy via affiliates } & & & & \\
\hline & \multicolumn{2}{|c|}{ Business Cycle } & \multicolumn{2}{|c|}{ Financial Cycle } & \multicolumn{2}{|c|}{ Business Cycle } & \multicolumn{2}{|c|}{ Financial Cycle } & \multicolumn{2}{|c|}{ Business Cycle } & \\
\hline & + & - & + & - & + & - & + & - & + & - & \multicolumn{2}{|c|}{+} \\
\hline General capital requirements & & $\mathrm{CH}$ & & & $\mathrm{KR}, \mathrm{MX}$ & TR & & HK & $\mathrm{DE}$ & US & & $\mathrm{FR}$ \\
\hline Sector specific capital buffer & PT & TR & & & $\mathrm{KR}, \mathrm{PL}, \mathrm{US}$ & UK & & PT, US & & DE & IT & \\
\hline Loan-to-value ratio limits & & $\mathrm{CL}, \mathrm{DE}$ & & $\mathrm{TR}$ & & & $\mathrm{KR}, \mathrm{PT}, \mathrm{TR}$ & & & & & \\
\hline Reserve requirements: Foreign $\ddagger$ & $\mathrm{MX}$ & & $\mathrm{DE}, \mathrm{PT}$ & & & DE & $\mathrm{KR}$ & & & $\mathrm{DE}$ & CA & \\
\hline Reserve requirements: Localł & $\mathrm{MX}$ & $\mathrm{CL}, \mathrm{PT}$ & & & $\mathrm{CL}, \mathrm{TR}$ & & $\mathrm{KR}, \mathrm{PT}, \mathrm{TR}$ & $\mathrm{DE}$ & & $\mathrm{NL}$ & & \\
\hline Interbank exposure limit $\ddagger$ & & $\mathrm{TR}$ & $\mathrm{TR}$ & & $\mathrm{KR}$ & UK & $\mathrm{KR}$ & $\mathrm{TR}$ & & & & \\
\hline Concentration ratio $\ddagger$ & PT & & & $\mathrm{TR}$ & TR & $\begin{array}{c}\mathrm{KR}, \mathrm{MX} \\
\mathrm{PL}, \mathrm{PT}\end{array}$ & TR & $\mathrm{DE}$ & & NL & CA & \\
\hline Countries reporting & \multicolumn{4}{|c|}{$\mathrm{CH}, \mathrm{CL}, \mathrm{DE}, \mathrm{MX}, \mathrm{PT}, \mathrm{TR}, \mathrm{UK}, \mathrm{US}$} & \multicolumn{4}{|c|}{$C L, D E, H K, K R, M X, P L, P T, T R, U K, U S$} & \multicolumn{4}{|c|}{ CA, DE, FR, IT, NL, US } \\
\hline
\end{tabular}




\section{Appendix A. Specific Regression Models by Transmission Channel}

\section{Appendix A.1 Inward Transmission through Home Global Banks}

The analysis of the inward transmission channel begins with a specification focused on changes in the domestic lending behavior of a domestic bank with activities in multiple foreign countries. This global bank is exposed to foreign prudential instruments through its exposure to foreign markets. Lending behavior at home may be affected. For example, as discussed in Section 2.1, if foreign regulations tighten, lending on the home market is, ceteris paribus, more attractive.

Formally, log changes in the stock of (domestic) loans $\left(\Delta Y_{b, t}\right)$ are linked to prudential changes weighted by a bank's lagged foreign exposures $\left(\operatorname{Exp}_{b, t-1}\right)$, bank-level controls $\left(X_{b, t-1}\right)$ as well as bank- and time fixed effects $\left(f_{b}, f_{t}\right)$ :

$$
\Delta Y_{b, t}=\alpha_{0}+\left(\alpha_{1} \operatorname{Exp}_{b, t}+\alpha_{2} \operatorname{Exp}_{b, t-1}+\alpha_{3} \operatorname{Exp}_{b, t-2}\right)+\alpha_{4} X_{b, t-1}+f_{b}+f_{t}+\epsilon_{b, t}
$$

Time fixed effects capture changes in prudential instruments on the home market. In order to test whether policies have a significant impact on lending growth, the F-test $\alpha_{1}+\alpha_{2}+\alpha_{3}=0$, considers whether the cumulative impact of regulations over a time horizon of three quarters is statistically significant.

In a second step, the prudential measures are interacted with bank-level variables to test whether the banks' business models influence the lending response to regulatory changes:

$$
\begin{aligned}
\Delta Y_{b, t}= & \alpha_{0}+\left(\alpha_{1} \operatorname{Exp}_{b, t}+\alpha_{2} \operatorname{Exp}_{b, t-1}+\alpha_{3} \operatorname{Exp}_{b, t-2}\right)+a_{4} X_{b, t-1}+\left(\beta_{1} \operatorname{Exp}_{b, t} \cdot X_{b, t-1}+\right. \\
& \left.\beta_{2} \operatorname{Exp} P_{b, t-1} \cdot X_{b, t-1}+\beta_{3} \operatorname{Exp}_{b, t-2} \cdot X_{b, t-1}\right)+f_{b}+f_{t}+\epsilon_{b, t}
\end{aligned}
$$

The corresponding F-tests are $\alpha_{1}+\alpha_{2}+\alpha_{3}=0, \beta_{1}+\beta_{2}+\beta_{3}=0, \sum_{i=1}^{3}\left(\alpha_{i}+\beta_{i} \cdot \bar{X}_{b, t-1}\right)$ and $\left(\alpha_{1}+\beta_{1} \cdot \bar{X}_{b, t-1}\right)$. The country team analyses allow effects of the bank-level variables to depend on the specific prudential measure considered. Take the case of prudential instruments aiming at increasing the capital buffers of banks. For well-capitalized banks with large capital buffers in excess of the regulatory minimum, higher capital requirements abroad should have little impact on domestic lending. For weakly capitalized banks with foreign subsidiaries, additional capital requirements may well be the relevant constraint, hence these banks may have to cut back foreign lending and possibly domestic lending in the short-run. Therefore, the expected sign of the interaction term between capital-based prudential changes and bank capital is negative in this inward transmission exercise.

An additional specification examined by teams allows for the effect of the foreign prudential instrument to vary over the home financial or business cycle. The resulting specification is 


$$
\Delta Y_{b, t}=\alpha_{0}+\alpha_{1} \operatorname{Exp}_{c u m, b, t-1}+\alpha_{2} X_{b, t-1}+\alpha_{3} \operatorname{Exp}_{c u m, b, t-1} \cdot Z_{t}+f_{b}+f_{t}+\epsilon_{b, t}
$$

where $Z_{t}$ is the credit-to-GDP or output gap in the home market. In order to measure the effect of the financial cycle, we use a cumulative regulatory measure $\left(\operatorname{Exp} P_{c u m, b, t-1}\right)$. The cumulative index captures not only contemporaneous changes in the policy but also previous changes that may affect current lending, surfacing at specific stages of the financial or business cycle, as in Akinci and Olmstead-Rumsey (2015) or by Cerutti, Claessens, and Laeven (2015).

\section{Appendix A.2 Inward Transmission through Affiliates of Foreign Banks}

Inward transmission of prudential instruments can arise through the lending behavior of home prudential policy via affiliates of foreign banks that are active in the domestic market. Rather than weighting foreign policy changes by the exposure of each domestic bank abroad, we now have a direct measure of the home policy changes of each foreign affiliate, depending on where the parent of this affiliate resides. Equation (1) thus becomes

$$
\begin{gathered}
\Delta Y_{b, j, t}=\alpha_{0}+\left(\alpha_{1} \text {HomeP }_{j, t}+\alpha_{2} \text { HomeP }_{j, t-1}+\alpha_{3} \text { HomeP }_{j, t-2}\right)+\alpha_{4} X_{b, t-1}+\alpha_{5} Z_{j, t}+ \\
f_{b}+f_{t}+\epsilon_{b, j, t}
\end{gathered}
$$

where $\operatorname{HomeP}_{j, t}$ is the regulation in the home country $j$ of an affiliate with a parent in $j$. Time fixed effects absorb changes in the regulation of the domestic market. Due to data limitations, it is usually not possible to control for the international loan portfolio of these banks through an exposure weighted index similar to the first inward transmission specification. Instead, a net intragroup position term in some specifications controls for the degree of ex ante reallocation of resources within the banking group. Also, bank fixed effects may capture structural differences in banks' business models. All other tests remain the same and interaction terms are modelled in analogy to equations (2) and (3).

\section{Appendix A.3 Outward Transmission through Home Global Banks}

The general structure of the outward transmission exercise is very similar to the structure of the inward transmission model. An initial specification starts with a given bank residing in country $i$ that has claims on several foreign countries $j$. To test how lending in these countries is affected by destination country regulatory policies implemented in each country $\mathrm{j}\left(\operatorname{Dest} P_{j, t}\right)$, formally the following empirical model is used:

$$
\begin{gathered}
\Delta Y_{b, j, t}=\alpha_{0}+\left(\alpha_{1} \operatorname{DestP}_{j, t}+\alpha_{2} \operatorname{DestP}_{j, t-1}+\alpha_{3} \operatorname{DestP}_{j, t-2}\right)+\alpha_{4} X_{b, t-1}+\alpha_{5} Z_{j, t}+f_{j}+ \\
f_{t}+f_{b}+\varepsilon_{b, j, t}
\end{gathered}
$$


All variables are defined as previously, except that the business or financial cycle variables $Z_{j, t}$ are now for the destination country $j$. The F-tests as well as interaction terms with banklevel variables and the cycle are conducted analogously.

The outward transmission exercise has a baseline specification that refers to prudential policies in the destination country. Another specification is similar to the inward transmission case in which teams consider exposure-weighted regulations in foreign countries that are not home or destination country. Consider, for instance, the foreign affiliate of the domestic bank located in a specific host market - say the U.K. - but with many foreign markets being serviced from that location. In that case, prudential changes imposed in those third country locations might affect the lending in the specific host market, and these prudential changes are included in the model through a composite index ExpP:

$$
\begin{aligned}
\Delta Y_{b, j, t} & =\alpha_{0}+\left(\alpha_{1} \operatorname{Dest}_{j, t}+\alpha_{2} \operatorname{Dest}_{j, t-1}+\alpha_{3} \operatorname{DestP}_{j, t-2}\right)+\alpha_{4} X_{b, t-1}+\alpha_{5} Z_{j, t}+ \\
\left(\beta_{1} \operatorname{Exp}_{b, t}\right. & \left.+\beta_{2} \operatorname{Exp}_{b, t-1}+\beta_{3} \operatorname{Exp}_{b, t-2}\right)+f_{j}+f_{t}+f_{b}+\varepsilon_{b, j, t}
\end{aligned}
$$

The corresponding F-test analyzes whether either destination country regulations or foreign-exposure weighted regulations in third countries have a significant impact over a horizon of three quarters on lending in a given destination market: $\alpha_{1}+\alpha_{2}+\alpha_{3}=0$; $\beta_{1}+\beta_{2}+\beta_{3}=0$. 


\section{Appendix B. Data Cleaning and Variable Definitions}

\section{Appendix B.1 Data Details and Cleaning}

Data availability, the length of time series, and the types of relevant banking groups vary across countries. As general guidance, country teams use quarterly data from the first quarter of 2000 through the fourth quarter of 2013. The largest meaningful set of banks is included in the baseline model implemented by country teams. The outward transmission exercises generally exclude foreign owned banks. Inward transmission exercises use data on domestic banks, foreign branches, and foreign subsidiaries.

Data have not been adjusted for exchange rate changes because not all country teams have information on the currency denomination of banks' cross-border assets. Whenever feasible and meaningful, positions adjusted for exchange rate changes were used for robustness specifications. Quarterly growth rates of lending are based on nominal rather than real data in order to avoid adding noise from quarterly price changes.

A key consideration in understanding channels of transmission is the use of consolidated versus unconsolidated data, in particular for those banking organizations that maintain extensive international networks of affiliates. Consolidated data refer to the group level, reflecting balance sheet items for all individual banks that are within the organization. Unconsolidated data cover specific entities so that balance sheet items are at the level of an individual bank which is part of a larger bank holding company or banking group. Consolidation complicates an analysis of the international dimension of prudential spillovers as the geographical split of a bank's assets or liabilities by destination/country may be excluded. In baseline specifications, country teams generally use data that have been consolidated across parents and branches as relevant for the transmission exercise, but not for the entire bank holding company. If that option is not available, data that have been consolidated at the group level (parent, branches, and subsidiaries) are used. For those countries where neither is available and instead resort to locational data, group-level variables are included as bank-level controls.

Teams impose screens on the bank-level data to account for merger-induced changes and to correct errors in the data: (i) Log changes that exceed -100/+100 percent have been dropped. Compared to the winsorization of data at standard levels, this has the advantage of giving an approximately normal distribution of growth rates while keeping most observations in the sample. Country teams additionally use standard winsorization techniques to check robustness. (ii) Generally, zeros representing missing bank-level observations are dropped. (iii) Strings that did not include at least two years of consecutive observations generally are dropped. 
These data cleaning steps follow standard procedures in the literature by focusing on variation in bank-specific observations along the intensive margin and by eliminating large outliers. But there is also the possibility that some large extensive margin adjustments in response to prudential instruments are inadvertently excluded from the analysis. These steps, along with baseline specification's instructions designed to deliver maximum commonalities across country results on specific transmission channels, imply that the meta-analysis results provide a conservative, lower bound for international transmission of prudential instruments through banks.

\section{Appendix B.2 Construction of Regressors used in Probit Meta-Analysis}

Indicator Variables:

- Emerging Market: Equals one if the country team running a given regression is classified as an Emerging Market economy (as opposed to an Advanced Economy), and zero otherwise.

- Inward Exposure-Weighted: Equals one if the regression studies the inward transmission of foreign prudential regulation through domestic global banks, and zero otherwise.

- Outward Transmission: Equals one if the regression studies the outward transmission of policy through the international activities of domestically-owned banks, and zero otherwise.

- $P P^{*}$ Cycle Indicator: Equals one if the regression includes prudential instruments interacted with business and financial cycle variables, and zero otherwise. Note that these specifications are also exactly the specifications which use a cumulative prudential instrument measure.

- $\quad P P^{*}$ Bank Indicator: Equals one if the regression includes prudential instruments interacted with bank-level balance sheet variables, and zero otherwise.

- All PP Indicator: Equals one if the regression specification simultaneously includes all prudential instruments showing sufficient variation, and zero otherwise.

Non-Indicator Variables:

- \% Foreign Bank Ownership: Indicates the share of banks operating in the regression country in 2013 which are foreign-owned as derived from the Claessens and van Horen Database (2015).

- \% Tightening: Indicates the share of prudential instrument changes which represent tightenings (as opposed to loosenings), for a given country team, channel, and specific instrument.

- Log Observations (not shown): The log number of observations included in a regression specification.

- Constant Term (not shown) 